\title{
Teacher views on the curriculum of elementary school third grade science course Tarık Başar $^{* a}$, Esed Yağcı ${ }^{* * b}$

\author{
${ }^{a}$ Ahi Evran University, Faculty of Education, Kırşehir/Turkey
} \\ ${ }^{\mathrm{b}}$ Hacettepe University, School of Foreign Languages, Ankara/Turkey
}

Article Info

DOI: 10.31704/ijocis.2018.004

Article History:

Received 06 March 2018

Revised 09 May 2018

Accepted 30 May 2018

Online $\quad 30$ June 2018

\section{Keywords:}

Science education,

Science course,

Teacher views.

Article Type:

Research paper

\begin{abstract}
This study has been carried out with the aim of evaluating the Curriculum of Elementary School Third Grade Science Course, which has been implemented for the first time in the academic year of 2014-2015, based on the views of teachers. The general screening model has been employed in the study. This research has been conducted with the participation of 36 classroom teachers, who have been determined via maximum variety sampling method from schools that are classified as high level, medium level, and low level in terms of their success. These semi-structured interviews have been audio-recorded with the permission of the teachers. Content analysis has been used in order to analyze the data, The results of the study suggest that the teachers in all three school levels have positive views on the curriculum. According to the teachers, the fact that the curriculum does not offer any activity examples on the teaching-learning process and students' workbook are what the curriculum lacks.
\end{abstract}

\section{ilkokul 3. Sınıf fen bilimleri dersi öğretim programına yönelik öğretmen görüşleri}

\begin{tabular}{ll} 
Makale Bilgisi \\
\hline DOI: $10.31704 /$ ijocis.2018.004 \\
\hline \multicolumn{2}{l}{ Makale Geçmişi: } \\
Geliş & 06 Mart 2018 \\
Düzeltme & 09 Mayıs 2018 \\
Kabul & 30 Mayıs 2018 \\
Çevrimiçi & 30 Haziran 2018
\end{tabular}

Anahtar Kelimeler:

Fen eğitimi,

Fen bilimleri dersi,

Öğretmen görüşleri.

\section{Makale Türü:}

Özgün Makale

\section{Öz}

Bu araştırma ilk kez 2014-2015 öğretim yılında uygulamaya başlanılan Illkokul 3. Sınıf Fen Bilimleri Dersi Öğretim Programını öğretmen görüşleri doğrultusunda değerlendirmek amacıyla yapılmıştır. Araştırmada, genel tarama modeli kullanılmıştır. Araştırma, Ankara ilinde başarı düzeyi açısından üst, orta ve alt düzey olarak gruplara ayrılan okullardan maksimum çeşitlilik örnekleme yöntemiyle belirlenmiş 36 sınıf öğretmeninin katılımıyla gerçekleştirilmiştir. Öğretmenlerle gerçekleştirilen yarı yapılandırılmış görüşmeler, öğretmenlerin izni alınarak, ses kayıt cihazına kaydedilmiştir. Araştırmada elde edilen verilerin analizinde ise içerik analizinden yararlanılmıştır. Araştırma sonucunda, her üç okul grubunda da öğretmenlerin programa yönelik olumlu görüşlere sahip oldukları belirlenmiştir. Öğretmenler, programda öğretme-öğrenme sürecine yönelik etkinlik örneklerinin yer almamasını ve öğrenci çalışma kitabının olmamasını ise programın eksik yönleri olarak görmektedir.

\footnotetext{
* Author: tarik.basar@ahievran.edu.tr

** Author: esed@hacettepe.edu.tr
}

Orcid ID: https://orcid.org/0000-0002-2653-0435 Orcid ID: https://orcid.org/0000-0002-5418-1172 


\section{Introduction}

Today, there is a scientific and technological competition among countries. The countries that are aware of this situation consider science courses as the address to be placed near the top in this competition. Accordingly, they also review science education in schools and make radical innovations in science programs (Çepni \& Çil, 2013). In other words, the countries wishing to take the lead in scientific and technological competition know that effective science education can only be achieved through well-prepared curricula. One of the most important indicators of an effective science education is the training of science literate individuals. In this respect, it has been aimed to educate science literate individuals primarily in the science programs that have been developed since 2005 in our country. Science literate individuals are defined in the science curriculum as "the ones who can research-inquire, make effective decisions, solve problems, communicate effectively and the ones who have self-confidence, are open to cooperation and are life-long learners with the awareness of sustainable development" (MEB, 2013). It is an irrefutable fact that the individuals who have these characteristics and who are science literate can find a place near the top in the science and technology race thanks to these qualities.

According to Fidan (1986), "all the activities planned to realize the objectives set out the curriculum design and the outlook of these in application constitutes the curriculum". Curriculum includes specific objectives, educational situations that enable achieving these goals, and test cases that show how well these goals have been achieved.

One of the most important ways to decide how effective a curriculum developed on the basis of the three values mentioned above in practice is to consult the opinions of teachers who are the practitioners of the program. When the literature is reviewed, it is observed that the majority of curriculum evaluation studies conducted in Turkey have also been performed based on teachers' opinions. The studies conducted by Yigit and Kurt (2002), Özdemir (2006), Aydın (2007), Şeker (2007), Kara (2008), Topal (2009), Boyacı (2010), Aybek and Aslan (2015) are some examples to this. This study also aimed to determine the effectiveness of the Primary School Third Grade Science Curriculum started to be implemented since 2014-2015 academic year based on teachers' views.

2013 Science Curriculum was developed as a reflection of $4+4+4$ education system. The curriculum has been gradually implemented throughout the country since the 2013-2014 academic year. While the program started to be applied at the middle school level in 2013-2014 academic year beginning from the fifth grade, it started to be applied in 2014-2015 academic year at the primary school level from the third grade.

With the gradual introduction of the new Science Curriculum since 2013-2014 academic year, the Science and Technology Curriculum developed in 2005 was also gradually abolished. As it is seen from the name of the curricula, the name of the course "Science and Technology" has been changed to "Science" with the new curriculum.

The most important innovation that the new curriculum has brought in terms of science education is giving science lessons in the first years, beginning from the 3rd grade. In the previous curriculum, which was called Science and Technology developed in 2005, science lessons had been given in primary school starting from the 4 th grade. So, with the new curriculum, students have started having science lessons one year before. Within the scope of the research, teachers were asked about their opinions on giving science lesson at 3rd grade level. It is believed that the opinions of teachers who are practitioners of this change are very valuable. These views will help provide a perspective on all dimensions of the curriculum, in other words, implicit, neglected, and extra curriculum dimensions apart from the formal applied curriculum.

In the 2013 Curriculum, as in every grade level, there are outcomes and topics at the level of 3rd grade, but there are no examples for the activities related to the outcomes and topics. In the Curriculum of Primary School 3rd Grade Science Course, there are no examples of activities aimed at the evaluation process that will show the whether goals have been achieved or not during teaching- learning process. The reason why there are no activity examples in the curriculum is that the teachers might have been expected to find appropriate activities taking the individual differences of students and environmental conditions into account both in the evaluation and teaching-learning process. However, in the 2005 Curriculum, there had been examples of activities that would guide teachers towards the teaching-learning process as well as the evaluation process.

In this context, although it is the teachers' responsibility to create activities for the teaching-learning or evaluation process, it may be helpful to include sample activities in the program in terms of guiding teachers in creating their own activity examples. In addition, it can be said that the teachers will need more assistance when considering the fact that teachers were not given a guidebook, which had been previously given with the 2005 curriculum, along with the 2013 curriculum regarding science course. Many studies on science curricula 
support this view. It has been determined that in the studies done by Gökçe (2006), Bayrak (2009), Topal (2009), Kılıç (2010) and Demirtaş (2012) teachers make use of the teacher's guidebook while applying the program. In this study, teachers who are the practitioners of this program were asked about their opinions. It is thought that the opinions of the teachers about the fact that the activity samples are not included in the primary school 3rd grade science curriculum is very important. Thus, it can be determined whether teachers need sample activities to guide them while preparing their activity examples or not.

In the research, the opinions of the teachers about the changes in the science education with the new curriculum, as well as the goals of the program, the content, the teaching-learning and evaluation processes, the duration of the lesson, the difficulties encountered while applying the program have been tried to be determined. The findings are expected to provide significant contributions in the course of the reorganization and development of the curriculum.

Within the scope of the research, teachers' views towards the curriculum were asked at the end of 20142015 academic year, when the program first started to be implemented at the 3rd grade level. In the study, it is thought that teachers' views on the strengths and weaknesses of the curriculum and the problems they have encountered in practice in the first year implementation of the curriculum would provide important clues for the early decisions about the program.

\section{Purpose of the Research}

This research was carried out in order to evaluate the Primary School 3rd Grade Science Teaching Curriculum which was started to be implemented in 2014-2015 academic year in terms of acquisition, content, learning-teaching processes and evaluation dimensions based on teacher opinions.

\section{Research Model}

\section{Method}

The study was a qualitative study conducted using general screening model. According to Karasar (2006), this model is a screening regime on the whole or the sample of the universe to arrive at a general judgement about the universe in an environment composed of a large number of elements.

\section{Sampling}

In the survey, primary schools located in Ankara province were divided into three groups as "upper level, middle level and lower level" in terms of achievement level. In order to determine upper, middle and lower level schools, the primary schools in the province of Ankara were ranked according to average the 2011 SBS (Level Placement Exam) scores. According to this ranking, the schools in the first $27 \%$ were upper level, the schools in the lower $27 \%$ were lower, and the rest was determined as first $27 \%$ and the lower $27 \%$ were medium level schools. In the study, the teachers who were interviewed were determined by maximum diversity sampling method which is one of the purposeful sampling methods. In the study, it was taken as basis for teachers to work in different schools in terms of success level in accordance with maximum diversity sampling method. Accordingly, a total of 36 classroom teachers, 12 of each of the school groups, were interviewed. Numerical data related to the demographic information of the interviewed teachers are presented in Table 1.

Table 1.

Numerical Data Related to Teachers' Demographic Information.

\begin{tabular}{lcccccc}
\hline $\begin{array}{l}\text { School Achievement } \\
\text { Level }\end{array}$ & Mender & Female & $\mathbf{0 - 5}$ years & $\mathbf{5 - 1 0}$ years & $\mathbf{1 0 - 2 0}$ years & $\begin{array}{c}\mathbf{2 0} \text { years } \\
\text { and over }\end{array}$ \\
\cline { 2 - 6 } & 5 & 7 & 2 & 3 & 3 & 4 \\
\hline Senior level & 4 & 8 & 3 & 3 & 3 & 3 \\
Intermediate level & 1 & 11 & 2 & 3 & 5 & 2 \\
Lower level & &
\end{tabular}

\section{Data Collection Tool}

A semi-structured interview form was prepared by the researcher in order to determine the opinions and suggestions of the teachers who are the practitioners of the 3rd grade science curriculum. The opinions of a total of 7 experts working as classroom teachers, curriculum development and assessment about the prepared draft interview form were obtained and necessary revisions were made in the interview form in line with the feedbacks. Harmonization among experts was calculated using the Krippendorff alpha technique. The 
calculated alpha value is 0.84 . This value also indicates that there is a high level of compliance among the experts who were interviewed (Krippendorff, 2004). Moreover, in order to test the clarity and functioning of the questions in the prepared interview form, pre-application was carried out with 5 primary school 3rd grade teachers and it was determined that the teachers generally well understood the questions in the interview form. After the preliminary application, the interview form consisting of 12 questions was finalized.

\section{Analysis of Data}

The semi-structured interviews with teachers were recorded on a voice recorder upon their consents. Each interview recorded on the voice recorder was then transcribed by the researcher. Content analysis was performed on the transcript data. For this purpose, the obtained data was examined and the codes were first determined for each interview question, and then similar codes were put together to create themes. Teachers' views towards the curriculum were also described on the basis of the determined codes and themes and described data was interpreted in the light of these representations. Within the scope of the research, direct citation for each interview question was also included in order to reflect teachers' views on the curriculum. In addition, frequency and percentage calculations were done for each school group classified as upper, middle and lower level in terms of the determined code and the success level of the themes.

In order to determine the reliability of the codes generated by the researcher, the data obtained from the interview form was also coded by another researcher and the codes determined by both researchers were compared. The reliability between the codes determined by both researchers was calculated using the formula proposed by Miles and Huberman (1994) (Number of consensus unions / Consensus union + Number of consensus). Within the scope of this formula, the percentage of agreement between the two researchers or the identified codes was calculated as 0.88. According to Yıldırım and Şimşek (2011), it can be said that the reliability the interview data is sufficient when it is $70 \%$ and above (Yıldırım \& Şimşek, 2011).

\section{Being Informed About The Program}

\section{Findings}

The opinions obtained from the interviews with the teachers regarding the interview question "Did teachers have any information about the curriculum before the Curriculum of Primary School 3rd Grade Science Course was implemented?" and the frequency distributions related to these opinions are presented in Table 2.

Table 2.

Frequency Distribution of Teachers' Views on Information about the Curriculum.

\begin{tabular}{llcccc}
\hline & Codes & $\begin{array}{c}\text { Top } \\
\text { Theme }\end{array}$ & $\begin{array}{c}\text { Middle } \\
\text { Group }\end{array}$ & $\begin{array}{c}\text { Sub } \\
\text { Group }\end{array}$ & Total \\
\cline { 2 - 5 } & f & $\mathbf{f}$ & $\mathbf{f}$ & $\mathbf{f}$ \\
\hline $\begin{array}{l}\text { Opinions Regarding } \\
\text { Information About the }\end{array}$ & $\begin{array}{l}\text { I had no information about the } \\
\text { curriculum } \\
\text { I have informed about the } \\
\text { curriculum myself via internet }\end{array}$ & 11 & 12 & 11 & 34 \\
& & 1 & - & 1 & 2 \\
\hline
\end{tabular}

When Table 2 is reviewed; it seems that the vast majority of teachers did not have any information about the curriculum before the 3rd Grade Science Teaching Curriculum started to be implemented. Some of the teachers' views on this question are as follows:

UT-8: (Teacher working at a school in the upper group as an achievement level):

"...No information was given. When we started the curriculum program, seminar work, we would have the science lesson this year in the 3rd grade. Then we were informed. No prior information was given..."

MT-4: (Teacher working in a middle school group as an achievement level):

"...No, we did not know about the curriculum. We came in September. It was a surprise. They said you have a science class..."

ST-2: (Teacher who works in a sub-group as an achievement level):

"...I just downloaded the contents of the curriculum from the sites I followed on the internet and followed them by myself. In other words, I have the knowledge as a result of my own studies. Neither at the end of the 2nd year, nor at the beginning did I get any information..." 


\section{Teaching Science Course at the 3rd Grade}

The opinions obtained from the interviews with the teachers regarding the interview question "What are the opinions of teachers about the teaching the Science course at the 3rd grade?" and the frequency distributions related to these opinions are presented in Table 3.

Table 3.

Frequency Distribution of Opinions of Teachers about teaching Science Course in Grade 3 at Primary School.

\begin{tabular}{|c|c|c|c|c|c|c|}
\hline Theme & Sub-theme & Codes & $\begin{array}{c}\text { Top } \\
\text { Group }\end{array}$ & $\begin{array}{l}\text { Middle } \\
\text { Group }\end{array}$ & $\begin{array}{c}\text { Sub } \\
\text { Group }\end{array}$ & Total \\
\hline & & & $f$ & $f$ & $f$ & $f$ \\
\hline $\begin{array}{l}\text { Opinions on the } \\
\text { science course in the } \\
3^{\text {rd }} \text { grade of primary } \\
\text { school }\end{array}$ & $\begin{array}{l}\text { I think it is positive } \\
\text { that the science topics } \\
\text { are given in the } \\
\text { Science course }\end{array}$ & $\begin{array}{l}\text { I think that the } \\
\text { students increase their } \\
\text { knowledge on science } \\
\text { I think students are } \\
\text { prepared for the } 4^{\text {th }} \\
\text { grade science class }\end{array}$ & 7 & 8 & 9 & 24 \\
\hline
\end{tabular}

When Table 3 is reviewed; it is seen that in all three school groups, all of the teachers have positive views about giving science subjects in the third year of primary school. It was determined that 7 teachers working in the upper group; 8 teachers in the middle group and 9 teachers in the lower group thought that giving science courses in the 3rd grade primary school increased students' science knowledge. In addition, 8 teachers working in the upper group; 4 teachers in the middle group and 6 teachers in the sub-group found the 3rd grade science course as helpful since it prepares students for the 4th grade science course. Some of the teachers' views on this question are as follows:

UT-7: "...Well; Very good in terms of being a preparation for the 4th grade in the 3rd year..."

MT-12: "...In fact it's good that they were separated. Positive. There are so many topics in life science; as if I were in the science department, and it seemed to be useless in the meantime. Or it was very boring in the lesson of life science. It is good to separate science. It is more interesting for the children. Also, it seems to me that they felt they grew up since they took a separate science course..."

ST-8: "...The present topics were not in the curriculum in the past years, for example, electricity topic or the structure of world. So I think it's good. Positive, because they used to meet with the topic for the first time in the 4th grade and it used to be harder. At least it is a step, as simple as they would understand. It's good. Positive, I think..."

\section{Achievements of the Curriculum}

The opinions obtained from the interviews with the teachers regarding the interview question "What are the views of teachers on their achievements in the curriculum of the 3rd grade primary science course?" and the frequency distributions related to these opinions are presented in Table 4.

Table 4.

Frequency Distribution of Teachers' Opinions about Curriculum Achievements.

\begin{tabular}{|c|c|c|c|c|c|}
\hline \multirow[t]{2}{*}{ Theme } & \multirow[t]{2}{*}{ Codes } & Top Group & $\begin{array}{l}\text { Middle } \\
\text { Group }\end{array}$ & Sub Group & Total \\
\hline & & $f$ & $f$ & $f$ & $f$ \\
\hline \multirow{3}{*}{$\begin{array}{l}\text { Opinions } \\
\text { Regarding the } \\
\text { Gains }\end{array}$} & $\begin{array}{l}\text { Achievements are appropriate to } \\
\text { the level of students }\end{array}$ & 11 & 11 & 11 & 33 \\
\hline & $\begin{array}{l}\text { Achievements are suitable for } \\
\text { meaningful learning }\end{array}$ & 11 & 10 & 10 & 31 \\
\hline & $\begin{array}{l}\text { Achievements are available with } \\
\text { school resources }\end{array}$ & 11 & 5 & 2 & 18 \\
\hline
\end{tabular}

When Table 4 is examined, it is seen that 11 teachers in each of the three school group found the achievements appropriate for the level of the students. It was determined that 11 teachers working in the upper group and 10 teachers in the middle and lower groups thought that the achievements were appropriate for meaningful learning, meaning that the achievements were not in a fashion that led students to memorization.

Some of the teachers' views on this question are as follows:

UT-10: "...So achievements can be reached. We are a bit lucky as a school, having the laboratory but I do not know about other schools..." 
MT-9: "...The achievements are absolutely appropriate for the level. Absolutely appropriate, so we did not have any problems..."

ST-1: "... find it appropriate to learn meaningfully; not learning by heart..."

\section{Topics covered in the program}

The opinions obtained from the interviews conducted with the teachers regarding the interview question "What are the opinions of teachers about the topics covered in the curriculum of the 3rd grade science course?" and the frequency distributions related to these opinions are presented in Table 5.

Table 5.

Frequency Distribution of Teachers' Opinions about the Topics in the Program.

\begin{tabular}{llccccc}
\hline \multirow{2}{*}{ Theme } & Codes & Top Group & $\begin{array}{c}\text { Middle } \\
\text { Group }\end{array}$ & Sub Group & Total \\
\cline { 3 - 6 } & & $\mathbf{f}$ & $\mathbf{f}$ & $\mathbf{f}$ & $\mathbf{f}$ \\
\hline Opinions on & Topics are appropriate for the level & 11 & 10 & 10 & 31 \\
the topics & of students & 11 & 10 & 10 & 31 \\
& Topics are suitable for achievements & 12 & 12 & 10 & 34 \\
\hline
\end{tabular}

When Table 5 is examined; all of the teachers working in upper and middle group; and 10 teachers in the sub-group found the subjects in the curriculum related to daily life. Some of the teachers' views on this question are as follows:

UT-7: "The achievements were perfectly equaled, that is, the topics are related to the achievements..."

MT-9: "... Associated with everyday life. So it has the information that age group can use in daily life. So when you teach the children about the subject, they can give examples from their daily lives ..."

ST-11: "...That is good for the level of my students. Suitable for grade 3. We have never had difficulty..."

\section{The Lack of sample Activities in the Curriculum}

The opinions obtained from the interviews with the teachers regarding the interview question "What are the views of teachers on the absence of sample activities for teaching-learning and assessment processes in the curriculum of the 3rd grade science course?" and the frequency distributions related to these opinions are presented in Table 6.

Table 6.

Frequency Distribution of Teachers' Opinions about Lack of Sample Activities in the Curriculum.

\begin{tabular}{llcccc}
\hline \multirow{2}{*}{ Theme } & Codes & Top Group & $\begin{array}{c}\text { Middle } \\
\text { Group }\end{array}$ & Sub Group & Total \\
\cline { 2 - 6 } & $\mathbf{f}$ & $\mathbf{f}$ & $\mathbf{f}$ & $\mathbf{f}$ \\
\hline $\begin{array}{l}\text { Opinions Regarding the } \\
\text { absence of Sample }\end{array}$ & $\begin{array}{l}\text { There should be examples } \\
\text { of activities for guidance } \\
\begin{array}{l}\text { Activities in the } \\
\text { I do not see the lack of } \\
\text { suriculum }\end{array}\end{array}$ & 12 & 11 & 11 & 34 \\
\hline
\end{tabular}

When Table 6 is examined, 11 teachers working in the middle and lower groups and all teachers in the upper group think that the teachers should be provided with sample activities in the curriculum in terms of guidance. Some of the teachers' views on this question are as follows:

UT-10: "...So it would have been better if there were. It could have been more guiding..."

MT-11: "...So we see that; even if there is not, it could be. Because the teacher is doing it himself..."

ST-7: "...t would be good if there were because it is easy for us. At least, it is an example in our hands..."

\section{Adequacy of Activities Conducted in Teaching-Learning Process}

The opinions obtained from the interviews with teachers on the interview question "What are the opinions of teachers on the adequacy level of the teaching-learning process they conducted in order to achieve the objectives of the program?" and the frequency distributions related to these opinions are presented in Table 7. 
Table 7.

Frequency Distribution of Teachers' Opinions on the Sufficiency of Activities Performed in the Teaching-Learning Process.

\begin{tabular}{|c|c|c|c|c|c|}
\hline \multirow[t]{2}{*}{ Theme } & \multirow[t]{2}{*}{ Codes } & Top Group & $\begin{array}{l}\text { Middle } \\
\text { Group }\end{array}$ & Sub Group & Total \\
\hline & & $f$ & $f$ & $f$ & $f$ \\
\hline \multirow{7}{*}{$\begin{array}{l}\text { Comments on } \\
\text { the adequacy } \\
\text { of the activities } \\
\text { in the teaching- } \\
\text { learning } \\
\text { process }\end{array}$} & $\begin{array}{l}\text { I make it relevant by linking the } \\
\text { subjects to daily life }\end{array}$ & 4 & 2 & 5 & 11 \\
\hline & $\begin{array}{l}\text { I conduct enough activities using } \\
\text { visual materials in class }\end{array}$ & 2 & 4 & 3 & 9 \\
\hline & $\begin{array}{l}\text { I make it enough by doing frequent } \\
\text { repetition on the subject }\end{array}$ & 2 & 3 & 1 & 6 \\
\hline & $\begin{array}{l}\text { I make it enough by doing } \\
\text { experiments about the subjects }\end{array}$ & 1 & 2 & - & 3 \\
\hline & $\begin{array}{l}\text { In class, I do enough group work to } \\
\text { make sure it is enough }\end{array}$ & 2 & - & - & 2 \\
\hline & $\begin{array}{l}\text { I think the lab is inadequate because } \\
\text { it does not have enough equipment }\end{array}$ & 1 & - & 3 & 4 \\
\hline & $\begin{array}{l}\text { I think classroom is inadequate as it } \\
\text { is crowded }\end{array}$ & - & 1 & - & 1 \\
\hline
\end{tabular}

When Table 7 is reviewed, since the 4 teachers who work in the upper group relate the subjects to daily life, and 4 teachers who work in the middle group use visual materials in class, it can be seen that 5 teachers who work in the sub-group found the activities they had done during the teaching-learning process to be sufficient because they associated the subjects with daily life. In addition, it was determined that 1 teacher working in the upper group and 3 teachers in the lower group found the activities they had done during the teachinglearning process to be inadequate because the laboratory did not have sufficient equipment. Some of the teachers' views on this question are as follows:

UT-9: "...I mostly assign the children group work. Here they worked in groups. Those children who were not willing to work then joined them..."

MT-4: "...Repeating often, even the weakest student in general is much better, because you give enough space and time..."

ST-4: "...It was more permanent in children when I taught visually. They liked more and more..."

\section{Preferred Assessment Tools}

The opinions obtained from the interviews with teachers regarding the interview question "What are the opinions of the teachers about the assessment tools they prefer to determine achievements of the objectives of the curriculum?" and the frequency distributions related to these opinions are presented in Table 8.

Table 8.

Frequency Distribution of Teachers' Opinions about Assessment Tools They Prefer.

\begin{tabular}{llcccc}
\hline \multirow{2}{*}{ Theme } & Codes & Top Group & $\begin{array}{c}\text { Middle } \\
\text { Group }\end{array}$ & Sub Group & Total \\
\cline { 3 - 6 } & & $\mathbf{f}$ & $\mathbf{f}$ & $\mathbf{f}$ & $\mathbf{f}$ \\
\hline \multirow{3}{*}{ Opinions on } & Multiple choice test & 8 & 9 & 9 & 26 \\
preferred & True-false test & 2 & 2 & 3 & 7 \\
assessment & Work sheets & 1 & 2 & 2 & 5 \\
tools & Participation in the course & 2 & 2 & 1 & 5 \\
& Oral presentation & 2 & 1 & 1 & 4 \\
& Self and peer evaluation & 2 & 1 & 1 & 4 \\
\hline
\end{tabular}

When Table 8 is examined; it is seen that 8 teachers working in the upper group, 9 teachers who worked in the middle group and the sub group preferred the multiple choice test. Some of the teachers' views on this question are as follows:

UT-4: "...There is a file that every student has put in all the work s/he has done, and I think this file gives enough information about what the learner has learned..." 
MT-8: "...At the end of each topic, I distribute the work sheets related to that subject to the students and I have an idea about how much the students have learned according to their work sheets..."

ST-12: "...I usually prepare and administer multiple-choice tests consisting of ten questions to the students..."

\section{Duration of the Course}

The opinions obtained from the interviews with the teachers regarding the interview question "What are the opinions of teachers on the duration of the primary school 3rd grade science course?" and the frequency distributions related to these views are presented in Table 9.

Table 9.

Frequency Distribution of Teachers' Opinions about Course Duration.

\begin{tabular}{|c|c|c|c|c|c|}
\hline \multirow[t]{2}{*}{ Theme } & \multirow[t]{2}{*}{ Codes } & Top Group & $\begin{array}{l}\text { Middle } \\
\text { Group }\end{array}$ & Sub Group & Total \\
\hline & & $f$ & $f$ & $f$ & $f$ \\
\hline \multirow{3}{*}{$\begin{array}{l}\text { Opinions } \\
\text { Related to the } \\
\text { Course } \\
\text { Duration }\end{array}$} & $\begin{array}{l}\text { The time given for the course is } \\
\text { sufficient }\end{array}$ & 11 & 7 & 9 & 27 \\
\hline & $\begin{array}{l}\text { The time given for the course must } \\
\text { be reduced }\end{array}$ & - & 2 & 1 & 3 \\
\hline & $\begin{array}{l}\text { The time given for the course should } \\
\text { be increased }\end{array}$ & 1 & 3 & 2 & 6 \\
\hline
\end{tabular}

When the Table 9 is reviewed it can be seen that 11 teachers working in the upper group, 7 teachers in the middle group and 9 teachers in the lower group found the time allocated for the 3rd grade science courses in primary school as sufficient.

Some of the teachers' views on this question are as follows:

UT-7: "...Enough, that is enough for the subjects. So 3 hours is really nice for the topics..."

MT-7: "...Time is enough. So these subjects match up with these achievements..."

ST-4: "...I now say that I finished the units earlier. The duration should be reduced now. For example, it would be much better if it was given to Math instead..."

\section{Difficulties Encountered While Applying The Program}

The opinions obtained from the interviews with the teachers regarding the interview question "What are the views of the teachers about the difficulties they experienced when applying the Curriculum of Primary School Science Course, which was first implemented in the 2014-2015 year?" and the frequency distributions related to these opinions are presented in Table 10.

\section{Table 10.}

Frequency Distribution of Teachers' Opinions on whether They Had any Difficulties While Applying the Curriculum.

\begin{tabular}{|c|c|c|c|c|c|}
\hline \multirow[t]{2}{*}{ Theme } & \multirow[t]{2}{*}{ Codes } & Top Group & $\begin{array}{l}\text { Middle } \\
\text { Group }\end{array}$ & Sub Group & Total \\
\hline & & $f$ & $f$ & $f$ & $f$ \\
\hline $\begin{array}{l}\text { Opinions } \\
\text { Regarding the }\end{array}$ & $\begin{array}{l}\text { I have not experienced any } \\
\text { difficulties }\end{array}$ & 9 & 6 & 8 & 23 \\
\hline $\begin{array}{l}\text { Difficulty of } \\
\text { Implementing } \\
\text { the Curriculum }\end{array}$ & $\begin{array}{l}\text { I had some difficulties because of } \\
\text { the lack of teacher's guidebook }\end{array}$ & 3 & 6 & 4 & 13 \\
\hline
\end{tabular}

When Table 10 is reviewed; 9 teachers working in the upper group, 6 teachers in the middle group and 8 teachers in the lower group seem not to have a difficulty while applying the program.

Some of the teachers' views on this question are as follows:

UT-7: "...We had nothing with our guidebook. It's also difficult because we do not have a guide book..."

MT-3: "...t would be easier if we had our guide book..."

ST-11: "...I never had difficulty. Not such an extra work, did not bring a load, did not have difficulty..." 


\section{Strengths of The Curriculum}

The opinions obtained from the interviews with the teachers regarding the interview question "What are the views of the teachers on the strengths of the curriculum for the 3rd Grade Science Course in primary school?" and the frequency distributions related to these opinions are presented in Table 11.

Table 11.

Frequency Distribution of Teachers' Views on the Strengths of the Curriculum

\begin{tabular}{llcccc}
\hline & Codes & Top Group & $\begin{array}{c}\text { Middle } \\
\text { Group }\end{array}$ & Sub Group & Total \\
\cline { 2 - 6 } & & $\mathbf{f}$ & $\mathbf{f}$ & $\mathbf{f}$ & $\mathbf{f}$ \\
\hline Opinions about & Relevance to daily life & 7 & 8 & 6 & 21 \\
the strengths & Students' interest in science & 4 & 4 & 4 & 12 \\
of the & Appropriateness for students' level & 2 & 5 & 3 & 10 \\
curriculum & $\begin{array}{l}\text { Preparation of students for the 4 } \\
\text { th }\end{array}$ & 4 & - & 2 & 6 \\
\hline
\end{tabular}

When Table 11 is reviewed, 7 teachers working in the upper group, 8 teachers working in the middle group and 6 teachers working in the sub-group regarded the program to be related to daily life as one of the strengths of the program. Some of the teachers' views on this question are as follows:

UT-9: "...So the science is more about the kitchen in your home. It's my pleasure to go to the program because it's about what we see around. So it's about the child's life. For example; Here is the water. The child is living in it, he sees it in the kitchen, he sees electric vehicles at home. I mean, it's so nice that it's about the child's life..."

MT-3: "...It was suitable for the level of the children, I think the strongest side was it..."

ST-8: "...I had some concerns when I first heard about science course at the 3rd grade, how could be taught at the level of the 3rd grade, but they have simplified things very intensely. So it's good. It is a preparation for 4th grade..."

\section{Weaknesses of the Curriculum}

The opinions obtained from the interviews carried out with the teachers regarding the interview question "What are the views of teachers on the weaknesses of the Curriculum for the 3rd grade Science Class in Primary School ?" and the frequency distributions related to these opinions are presented in Table 12.

Table 12.

Frequency Distribution of Teachers' Views on the Weaknesses of the Curriculum.

\begin{tabular}{llcccc}
\hline \multirow{2}{*}{ Theme } & Codes & Top Group & $\begin{array}{c}\text { Middle } \\
\text { Group }\end{array}$ & Sub Group & Total \\
\cline { 3 - 6 } & No examples of activities in the & $\mathbf{f}$ & $\mathbf{f}$ & $\mathbf{f}$ & $\mathbf{f}$ \\
\hline \multirow{2}{*}{$\begin{array}{l}\text { Opinions on the } \\
\text { weaknesses of }\end{array}$} & program & 7 & 6 & 6 & 19 \\
the curriculum & No student workbook & 1 & 4 & 6 & 11 \\
& No teacher manual & 4 & 3 & 3 & 10 \\
& Short topics & 2 & 2 & 3 & 7 \\
\hline
\end{tabular}

When Table 12 is reviewed, 7 teachers working in the upper group, 6 teachers who work in the middle group and in the sub-group determined the lack of sample activities as one of the weaknesses of the curriculum. Some of the teachers' views on this question are as follows:

UT-3: "...Weak due to lack of a study book for students..."

MT-2: "...The school equipment is not fully equipped..."

ST-10: "...There are not any samples, we tried to complete it ourselves. There had to be some activities, it would have been much better. They are missing..."

\section{Suggestions Regarding the Curriculum}

The opinions obtained from the interviews conducted with the teachers regarding the interview question "What are the recommendations of the teachers for the development of the curriculum of the 3rd grade science course at the end of their implementations?" and the frequency distributions related to these opinions are presented in Table 13.

Table 13.

Frequency Distribution of Teachers' Suggestions Related to Curriculum. 


\begin{tabular}{|c|c|c|c|c|c|}
\hline \multirow[t]{2}{*}{ Theme } & \multirow[t]{2}{*}{ Codes } & Top Group & $\begin{array}{l}\text { Middle } \\
\text { Group }\end{array}$ & Sub Group & Total \\
\hline & & $f$ & $f$ & $f$ & $f$ \\
\hline \multirow{6}{*}{$\begin{array}{l}\text { Suggestions } \\
\text { Regarding } \\
\text { Program }\end{array}$} & $\begin{array}{l}\text { Sample activities should be put into } \\
\text { the curriculum }\end{array}$ & 8 & 8 & 7 & 23 \\
\hline & $\begin{array}{l}\text { Student workbooks should be } \\
\text { prepared }\end{array}$ & 5 & 4 & 4 & 13 \\
\hline & $\begin{array}{l}\text { Laboratory materials should be sent } \\
\text { to schools }\end{array}$ & 1 & 5 & 6 & 12 \\
\hline & $\begin{array}{l}\text { Teacher guidebooks should be } \\
\text { prepared }\end{array}$ & 3 & 3 & 3 & 9 \\
\hline & Topics should be detailed & 1 & 2 & 2 & 5 \\
\hline & $\begin{array}{l}\text { Textbook should be visually } \\
\text { enriched }\end{array}$ & - & 1 & 2 & 3 \\
\hline
\end{tabular}

When Table 13 is reviewed; 8 teachers who work in the upper group and the middle group and 7 teachers who work in the lower group recommend that there should be activity examples in the curriculum. Some of the teachers' views on this question are as follows:

UT-12: "... Will be much more successful if activities are placed..."

MT-2: "...If the workbook and the teacher's guidebook are given to you by the Ministry of National Education; I believe there will be much more success in science class..."

ST-11: "...I do not think that the resources in the school that is the resources in the laboratory are adequate. The materials for primary schools should be further developed by the ministry; I think it will be funnier and more efficient for children to learn the lessons..."

\section{Discussion, Conclusion and Recommendations}

When the findings obtained within the scope of the research were examined, it was determined that no information was given to the teachers about the Science Curriculum, to be implemented for the first time at the third grade before its nation-wide implementation. Demirtaş, Arslan, Yarar and Tutkun (2015) also found similar results about the curriculum of the 5th grade science course implemented for the first time in the 20132014 academic year. The teachers participated in their study stated that they were not informed about the curriculum. Teachers who are not informed about the curriculum are likely to encounter problems in the process of applying a curriculum which will be implemented in that specific year for the first time. Many studies on science curricula support this view. Studies conducted by Savran, Çakıroğlu and Özkan (2002), Akpınar, Günay and Hamurcu (2005), Öz (2007), Şeker, (2007), Yangın (2007), Kara (2008), Tekbıyık and Akdeniz (2008) and Unayağyol (2009) also revealed that one of the main problems teachers faced during the implementation of science curricula was not being adequately informed about the curriculum.

Another important finding of the research is that in all three school groups, all of the teachers' find it positive that science subjects should be given as a separate course under the name of Science at the 3rd grade level. Similar findings have been obtained in many studies related to this topic in the field. Aybek and Aslan (2015), Çalışoğlu, Tortum, Erişmiş and Koçyiğit. (2015), Çifţ̧i, Saban, Gündüz and Olaç (2015), Ünişen and Kaya (2015) and Yıldırım and Güngör Akgün (2015) found that teachers were positive about giving science courses at the third grade level. In the first year of the Science Course, which was first offered in the 2014-2015 academic year, administering the science course at the 3rd grade can be interpreted as a positive step for the primary school science education depending on the teachers' views who are the practitioners of the curriculum. Teachers whose opinions were asked stated that the science course given in the 3rd grade increased the students' knowledge of science. In other words, the teachers think that in the 3rd grade science course, students are more interested in science than Life Science course. The study done by Topal (2009) supports this view. Topal's study (2009), classroom teachers stated that the students' knowledge of science subjects in science lessons is higher than that of science subjects in life science lessons. In addition, the teachers again stated that the students of the 3rd grade Science Course are prepared for the 4th grade Science Course. In other words, the teachers thought that the third grade science course better prepared students for the fourth grade science course than the life science course did. The studies done by Demir (2006) and Topal (2009) also support this view. In Demir's (2006) study, it was determined that classroom teachers found that they did not have enough life science lessons to prepare students for science classes. According to classroom teachers in Topal's study (2009), life science course partly prepared students for the science course. 
Another finding that draws attention about the results of the research is that, majority of teachers think that there should be example activities in the curriculum as a guide for the teachers. Teachers think that giving example activities in the curriculum will help them to plan teaching-learning and evaluation processes. In the science course applied for the first time in 2014-2015 academic year, when it is thought that teachers were not informed about the program and the teacher guidebooks were not given for the lessons; it may be fairly natural that teachers want to example activities to be included in the curriculum. The reason why the teachers request activity samples in the curriculum may be the involvement of such activities in the previous '2005 Science and Technology Course Curriculum for teachers because the studies conducted by Doğan (2009) and Kurtuluş and Çavdar (2011) on the 2005 curriculum show that teachers have positive thoughts about the example activities in the curriculum. In the study conducted by Doğan (2009), it was determined that the teachers have largely adopted and tried to apply the activities provided with the curriculum. Kurtuluş and Çavdar (2011) also revealed that the teachers found the activities in the curriculum as interesting and helpful for permanent learning.

Teachers generally point out that the program is overall positive but have some deficiencies. Teachers view the lack of activity samples as one of the missing aspects of the program. Teachers view the absence of a student workbook, which can be instead used as a way to reinforce what students learn, is another missing element of the curriuculum. Similar findings have been found in many studies on the Science Curriculum. Regarding the 3rd grade science curriculum, Çalışoğlu et al. (2015), Farmer et al. (2015) and Yıldırım and Güngör Akgün (2015) and regarding the 5th grade science curriculum Demirtaş et al. (2015) found that the teachers considered the absence of student workbooks as an important deficiency about the curriculum. In addition, as a success level, especially the teachers working in the middle and lower group schools stated that the weakness of the curriculum is due to the lack of equipment at schools. Similar findings have been obtained in many studies on science curricula. It was determined that the teachers considered the lack of equipment at schools as a negative feature of the curriculum in the studies conducted by Özdemir (2006), Şeker (2007), Kara (2008) and Boyaci (2010). When the literature on science courses is examined, it is seen that one of the main problems faced by teachers in the implementation of science curricula is the lack of equipment at schools. The studies conducted by Akdeniz et al. (2002), Savran et al. (2002), Öz (2007), Erdem (2009), Unayağyol (2009), Demirtaş (2012), Aybek and Aslan (2015) and Çalışoğlu et al. (2015), Çiftçi et al. (2015) and Yıldırım and Güngör Akgün (2015) have revealed findings supporting this view.

On the basis of the results obtained in the research, it might be possible to suggest that the teachers who were not informed about the Curriculum of the 3rd Grade Science Course, should be provided with in-service training seminars and/or courses. Other suggestions based on the findings of the study could be the inclusion of sample activities towards teaching-learning and assessment processes, preparation of a guidebook for teachers when they apply the curriculum and preparation of a workbook that could help students reinforce what they have learned in the 3rd grade science course. Final suggestion that can be made in the direction of the opinions of the teachers working in the middle and lower group schools is that their opinions about the tools they need in science courses can be obtained and the necessary tools and materials could be send to the school laboratories to make them sufficient enough for the science courses.

\section{Acknowledgement}

This study is a part of first author's doctoral dissertation, supervised by the second author. 


\section{TÜRKÇE SÜRÜM}

\section{Giriş}

Günümüzde, ülkeler arasında bilimsel ve teknolojik bir yarış yaşanmaktadır. Bu durumun farkında olan ülkeler yarışta ön sıralarda yer almanın adresi olarak ise fen derslerini görmektedirler. Bu doğrultuda da okullardaki fen eğitimini tekrar gözden geçirmekte, fen programlarında köklü yenilikler yapmaktadırlar (Çepni \& Çil, 2013). Yani bilimsel ve teknolojik yarışta ön sıralarda yer almak isteyen ülkeler, etkili bir fen eğitiminin ancak iyi hazırlanmış eğitim programları aracılığıyla sağlanabileceğinin farkındadır. Etkili bir fen eğitiminin en önemli göstergelerinden birisi ise fen okuryazarı bireylerin yetiştirilmesidir. Bu doğrultuda, ülkemizde de 2005 yılından itibaren geliştirilen fen programlarında öncelikle fen okuryazarı bireyler yetiştirmek amaçlanmıştır. Fen okuryazarı bireyler ise fen programında; "araştıran-sorgulayan, etkili kararlar verebilen, problem çözebilen, kendine güvenen, işbirliğine açık, etkili iletişim kurabilen, sürdürülebilir kalkınma bilinciyle yaşam boyu öğrenen bireyler" olarak tanımlanmaktadır (M.E.B., 2013). Ülkelerin, bilim ve teknoloji yarışında da ancak programda belirtilen bu özelliklere sahip bireyler bir başka deyişle fen okuryazarı bireyler sayesinde ön sıralarda kendisine yer bulabileceği ise yadsınamaz bir gerçektir.

Fidan'a (1986) göre, "verilen hedefleri gerçekleştirmek üzere planlanan tüm faaliyetler eğitim program tasarısını ve bunların uygulamadaki görünümü ise eğitim programını oluşturmaktadır". Bir eğitim programı ise belli hedefleri, bu hedeflere ulaşılmasını sağlayan eğitim durumlarını ve bu hedeflere ne derece ulaşıldığını gösteren sınama durumlarını içermektedir.

Yukarıdaki üç öğe esas alınarak geliştirilen bir eğitim programının uygulamada ne düzeyde etkili olduğuna karar verebilmenin en önemli yollarından birisi ise programın birer uygulayıcısı olan öğretmenlerin görüşlerine başvurmaktır. Alan yazın incelendiğinde, Türkiye'de yapılan program değerlendirme çalışmalarının büyük çoğunluğunun da öğretmen görüşlerine dayalı olarak gerçekleştirildiği görülmektedir. Akdeniz, Yiğit ve Kurt (2002), Özdemir (2006), Aydın (2007), Şeker (2007), Kara (2008), Topal (2009), Boyacı (2010), Aybek ve Aslan (2015) vb. çalışmalar örnek olarak verilebilir. Yapılan bu çalışmada da ilk kez 2014-2015 öğretim yılında uygulamaya konulan ilkkokul 3. Sınıf Fen Bilimleri Dersi Öğretim Programının etkililiği programı, ilk kez 20142015 öğretim yılında uygulayan öğretmenlerin görüşleri doğrultusunda belirlenmeye çalışılmıştır.

2013 Fen Bilimleri Dersi Öğretim Programı, 4+4+4 eğitim sisteminin bir yansıması olarak geliştirilmiş bir programdır. Program, 2013-2014 öğretim yılından itibaren ülke çapında kademeli olarak uygulanmaya başlanmıştır. Program, ortaokul düzeyinde 2013-2014 öğretim yılında, beşinci sınıflardan itibaren uygulanmaya başlarken; ilkokul düzeyinde ise 2014-2015 öğretim yılında, üçüncü sınıflardan itibaren uygulanmaya başlanmıştır.

Yeni Fen Bilimleri Dersi Öğretim Programı́nın 2013-2014 öğretim yılından itibaren kademeli olarak uygulanmaya başlanmasıyla birlikte, 2005 yılında geliştirilen Fen ve Teknoloji Dersi Öğretim Programı da kademeli olarak uygulamadan kaldırılmıştır. Program isimlerinden de anlaşılacağı üzere yeni programla birlikte "Fen ve Teknoloji" olan dersin adı "Fen Bilimleri" olarak değiştirilmiştir.

Yeni programın fen eğitimi açısından getirdiği en önemli yenilik ise ilkokullarda fen derslerinin 3. sınıflardan itibaren verilmeye başlanmasıdır. Bir önceki programda yani 2005 yılında geliştirilen Fen ve Teknoloji Dersi Öğretim Programında fen dersleri ilkokullarda 4. sınıftan itibaren verilmekteydi. Yani yeni programla birlikte öğrenciler fen derslerini bir yıl önceden almaya başlamışlardır. Araştırma kapsamında, öğretmenlere bu duruma ilişkin yani 3. sınıf düzeyinde fen dersinin verilmesine ilişkin görüşleri de sorulmuştur. Dersin uygulayıcıları olan öğretmenlerin yapılan bu değişikliğe ilişkin görüşlerinin oldukça değerli olduğu düşünülmektedir. Bu görüşler, resmi programın dışında uygulanan, örtük, ihmal edilen ve ekstra program boyutlarına da başka bir ifadeyle programın bütün boyutlarına ilişkin bir bakış açısı kazandırılmasına yardımcı olacaktır.

2013 Programında, her sınıf düzeyinde olduğu gibi 3. sınıf düzeyinde de kazanımlar ve konular yer almakta fakat kazanımlar ve konulara ilişkin etkinlik örnekleri bulunmamaktadır. Yani illkokul 3. Sınıf Fen Bilimleri Dersi Öğretim Programında, kazanımlara ulaşılmasını sağlayacak öğretme-öğrenme sürecine yönelik veya bu kazanımlara ulaşılıp ulaşılmadığının belirlenmesini sağlayacak değerlendirme sürecine yönelik etkinlik örnekleri yer almamaktadır. Programda etkinlik örneklerine yer verilmemesinin nedeni, gerek öğretme-öğrenme sürecinde gerekse de değerlendirme sürecinde öğretmenlerin öğrencilerin bireysel özelliklerini, çevresel koşulları vb. durumları dikkate alarak kendi sınıfına uygun etkinlikleri kendilerinin bulmalarını sağlamak olabilir. Oysaki 2005 Programında gerek öğretme-öğrenme sürecine gerekse de değerlendirme sürecine yönelik öğretmenlere rehberlik edecek etkinlik örnekleri yer almaktaydı. Bu bağlamda, öğretme-öğrenme veya değerlendirme sürecine yönelik etkinlikleri oluşturmak öğretmenlerin sorumluluğunda olmasına rağmen, 
öğretmenlere kendi etkinlik örneklerini oluştururken yol gösterici olması açısından örnek etkinliklerin programda yer almasının da yararlı olabileceği düşünülebilir. Ayrıca 2013 fen programıyla birlikte öğretmenlere 2005 fen programına yönelik verilen öğretmen kılavuz kitabının da verilmediği düşünüldüğünde öğretmenlerin böyle bir yardıma daha fazla intiyaç duyacakları söylenebilir. Fen programları ile ilgili yapılan birçok çalışma da bu görüşü desteklemektedir. Gökçe (2006), Bayrak (2009), Topal (2009), Kılıç (2010) ve Demirtaş (2012) tarafından yapılan çalışmalarda, öğretmenlerin programı uygularken, öğretmen kılavuz kitabından yararlandıkları belirlenmiştir. Yapılan bu çalışmada, programın uygulayıııları olan öğretmenlerin bu konudaki görüşleri de alınmıştır. İlkokul 3. Sınıf Fen Bilimleri Dersi Öğretim Programında etkinlik örneklerinin yer almamasına ilişkin öğretmenlerin görüşlerinin oldukça önemli olduğu düşünülmektedir. Çünkü böylelikle öğretmenlerin, etkinlik örneklerini oluştururken kendilerine yol gösterici örnek etkinliklere ihtiyaç duyup duymadıkları da tespit edilebilecektir.

Araştırmada, öğretmenlerin yeni programla birlikte fen eğitiminde meydana gelen bu değişikliklere ilişkin görüşlerinin yanısıra, programın hedef, içerik, öğretme-öğrenme ve değerlendirme süreci, ders süresi, program uygulanırken karşılaşılan zorluklar gibi boyutlara yönelik de görüşleri tespit edilmiştir. Böylece programın uygulamadaki etkililiği bütün boyutlarıyla belirlenmeye çalışıımışır. Elde edilen bulguların, programın yeniden düzenlenmesi ve geliştirilmesi aşamalarında önemli katkılar sağlayacağı beklenmektedir.

Araştırma kapsamında, öğretmenlerin programa yönelik görüşleri, programın 3. sınıf düzeyinde ilk kez uygulanmaya başlandığı 2014-2015 öğretim yılının sonunda alınmıştır. Yapılan araştırmada, öğretmenlerin programın güçlü ve zayıf yönlerine ilişkin görüşlerinin ve uygulamada karşılaştıkları sorunların programın uygulandığı ilk yılda belirlenmesinin programla ilgili alınacak erken kararlar için önemli ipuçları sağlayacağı düşünülmektedir.

\section{Araştırmanın Amacı}

Bu araştırma, ilk kez 2014-2015 öğretim yılında uygulamaya başlanılan İlkokul 3. Sınıf Fen Bilimleri Dersi Öğretim Programını kazanım, içerik, öğrenme-öğretme süreçleri ve değerlendirme boyutları açısından öğretmen görüşleri doğrultusunda değerlendirmek amacıyla yapılmıştır.

\section{Araştırma Modeli}

\section{Yöntem}

Araştırma, nitel bir çalışma olup genel tarama modeli kullanılarak gerçekleştirilmiştir. Karasar'a (2006) göre, bu model, çok sayıda elemandan oluşan bir evrende evren hakkında genel bir yargıya varmak için evrenin tümü veya evrenden alınacak örneklem üzerinde yapılan tarama düzenlemeleridir.

\section{Örneklem}

Araştırmada, öncelikle Ankara ilinde yer alan ilkokullar başarı düzeyi açısında "üst düzey, orta düzey ve alt düzey" olmak üzere üç gruba ayrılmıştır. Araştırmada, üst düzey, orta düzey ve alt düzey okulları belirlemek için ise Ankara ilinde yer alan ilkokullar, 2011 SBS (Seviye Belirleme Sınavı) puan ortalamalarına göre sıraya dizilmiştir. Bu sıralamaya göre, ilk \%27'lik dilimde yer alan okullar üst düzey, alt \%27'lik dilimde yer alan okullar alt düzey ve ilk \%27'lik dilim ile alt \%27'lik dilim dışında kalan okullar ise orta düzey olarak belirlenmiştir. Araştırmada, görüşleri alınan öğretmenler ise amaçlı örnekleme yöntemlerinden biri olan maksimum çeşitlilik örnekleme yöntemi ile belirlenmiştir. Araştırmada, maksimum çeşitlilik örnekleme yöntemine uygun olarak öğretmenlerin başarı düzeyi açısından farklı okullarda görev yapmaları esas alınmıştır. Bu doğrultuda, okul gruplarının her birinden 12'şer olmak üzere toplam 36 sınıf öğretmeniyle görüşme yapılmıştır. Görüşme yapılan öğretmenlerin demografik bilgilerine ilişkin sayısal veriler Tablo 1'de verilmiştir.

Tablo 1.

Öğretmenlerin Demografik Bilgilerine ilişkin Sayısal Veriler.

\begin{tabular}{lcccccc}
\hline Okulun Başarı Düzeyi & Cinsiyet & \multicolumn{1}{c}{ Kıdem } \\
\cline { 2 - 6 } & Erkek & Kadın & 0-5 yıl & $\mathbf{5 - 1 0}$ yıl & $\mathbf{1 0 - 2 0}$ yıl & $\begin{array}{c}\text { 20 yıl ve } \\
\text { üzeri }\end{array}$ \\
\hline Üst düzey & 5 & 7 & 2 & 3 & 3 & 4 \\
Orta düzey & 4 & 8 & 3 & 3 & 3 & 3 \\
Alt düzey & 1 & 11 & 2 & 3 & 5 & 2 \\
\hline
\end{tabular}




\section{Veri Toplama Aracı}

Illkokul 3. Sınıf Fen Bilimleri Dersi Öğretim Programına ilişkin programın uygulayıcıları olan öğretmenlerin görüşlerini ve önerilerini belirlemek amacıyla araştırmacı tarafından yarı yapılandırılmış bir görüşme formu hazırlanmıştır. Hazırlanan taslak görüşme formuna ilişkin sınıf öğretmeni, program geliştirme ve ölçmedeğerlendirme uzmanlarından oluşan toplam 7 uzmanın görüşleri alınmış ve gelen dönütler doğrultusunda görüşme formunda gerekli düzeltmeler yapılmıştır. Görüşleri alınan uzmanlar arasındaki uyum ise Krippendorff alfa tekniği ile hesaplanmıştır. Yapılan hesaplama sonucunda alfa değeri 0.84 olarak belirlenmiştir. Bu değer de görüşleri alınan uzmanlar arasında yüksek düzeyde uyum olduğunu göstermektedir (Krippendorff, 2004). Ayrıca hazırlanan görüşme formunda yer alan soruların anlaşılılığını ve işlerliğini test etmek amacıyla 5 ilkokul 3. sınıf öğretmeniyle ön uygulama yapılmış ve bu ön uygulama sonucunda öğretmenlerin görüşme formunda yer alan soruları genel olarak anlaşılır buldukları tespit edilmiştir. Ön uygulama sonrasında ise 12 sorudan oluşan görüşme formuna son hali verilmiştir.

\section{Verilerin Analizi}

Öğretmenlerle gerçekleştirilen yarı yapılandırılmış görüşmeler, öğretmenlerin izni alınarak, ses kayıt cihazına kaydedilmiştir. Daha sonra ses kayıt cihazına kaydedilen her bir görüşme, araştırmacı tarafından transkript edilmiştir. Transkripti yapılan veriler üzerinde ise içerik analizi yapılmıştır. Bu amaçla, elde edilen veriler incelenerek öncelikle her bir görüşme sorusu için kodlar belirlenmiş ve daha sonra benzer kodlar bir araya getirilerek temalar oluşturulmuştur. Öğretmenlerin programa yönelik görüşleri de belirlenen bu kod ve temalar esas alınarak betimlenmiş ve bu betimlemeler ışığında görüşme verileri yorumlanmıştır. Araştırma kapsamında, öğretmenlerin programa ilişkin görüşlerini yansıtabilmek için her bir görüşme sorusu için doğrudan alıntılara da yer verilmiştir. Ayrıca belirlenen kod ve temaların başarı düzeyi açısından üst, orta ve alt düzey olarak ayrılan her bir okul grubu için frekans ve yüzde hesaplamaları gerçekleştirilmiştir.

Araştırmacı tarafından oluşturulan kodların güvenirliğinin belirlenmesi amacıyla, görüşme formundan elde edilen veriler başka bir araştırmacı tarafından da kodlanmış ve her iki araştırmacı tarafından belirlenen kodlar karşılaştırılmıştır. Her iki araştırmacı tarafından belirlenen kodlar arasındaki güvenirlik ise Miles ve Huberman (1994) tarafından önerilen formül (Görüş birliği sayısı / Görüş birliği + Görüş ayrılığı sayısı) kullanılarak hesaplanmıştır. Bu formül kapsamında, belirlenen kodlara ilişkin iki araştırmacı arasındaki uyuşum yüzdesi 0.88 olarak hesaplanmıştır. Yıldırım ve Şimşek'e (2011) göre bu yüzdenin \%70 ve üzeri olması yeterli olduğundan dolayı görüşme verilerinin analizi için güvenirliğin sağlandığı söylenebilir (Yıldırım \& Şimşek, 2011).

\section{Program Hakkında Bilgi Sahibi Olma}

\section{Bulgular}

“Öğretmenlerin, İlkokul 3. Sınıf Fen Bilimleri Dersi Öğretim Programı uygulanmaya başlanmadan önce programa ilişkin herhangi bir bilgileri var mıydı?” görüşme sorusuna ilişkin olarak öğretmenlerle yapılan görüşmelerden elde edilen görüşler ve bu görüşlere ilişkin frekans dağılımları Tablo 2'de verilmiştir.

Tablo 2.

Öğretmenlerin Program Hakkındaki Bilgilerine ilişkin Görüşlerinin Frekans Dağılımı.

\begin{tabular}{|c|c|c|c|c|c|}
\hline \multirow{2}{*}{ Tema } & \multirow{2}{*}{ Kodlar } & Üst Grup & Orta Grup & Alt Grup & Toplam \\
\hline & & $f$ & $f$ & $f$ & $f$ \\
\hline Program & $\begin{array}{l}\text { Program hakkında herhangi bir } \\
\text { bilgim yoktu }\end{array}$ & 11 & 12 & 11 & 34 \\
\hline $\begin{array}{l}\text { Hakkındaki } \\
\text { Bilgilere İlişkin } \\
\text { Görüşler }\end{array}$ & $\begin{array}{l}\text { Program hakkında internet } \\
\text { aracılığıla kendim bilgi sahibi } \\
\text { oldum }\end{array}$ & 1 & - & 1 & 2 \\
\hline
\end{tabular}

Tablo 2 incelendiğinde; Illkokul 3. Sınıf Fen Bilimleri Dersi Öğretim Programı uygulanmaya başlamadan önce öğretmenlerin büyük çoğunluğunun programa ilişkin herhangi bir bilgiye sahip olmadıkları görülmektedir. Öğretmenlerin bu soruya ilişkin görüşlerinden bazıları aşağıda verilmiştir:

Üö-8: (Başarı düzeyi olarak üst grupta yer alan bir okulda görev yapan öğretmen):

“...Hiç bilgi verilmedi. Program, seminer çalışmalarına başladığımızda dendi işte 3. sınıfta bu sene fen bilgisi dersini işleyeceğiz. O zaman haberimiz oldu. Önceden hiçbir bilgilendirme yapılmadı..."

oÖ-4: (Başarı düzeyi olarak orta grupta yer alan bir okulda görev yapan öğretmen):

“...Hayır, programa ilişkin bilgimiz yoktu. Eylül ayında geldik. Sürpriz. Fen dersiniz var dendi..."

AÖ-2: (Başarı düzeyi olarak alt grupta yer alan bir okulda görev yapan öğretmen): 
"...Sadece internetten takip ettiğim sitelerden programın içeriğiyle ilgili şeyleri indirdim ve kendim takip ettim. Yani kendi çalışmalarım sonucunda bilgi sahibi oldum. Yoksa bununla ilgili ne sene sonunda yani 2. sınıfı bitirirken ne de sene başında bize bir bilgi iletilmedi..."

\section{Sınıf Düzeyinde Fen Bilimleri Dersinin Verilmesi}

“Öğretmenlerin, 3. sınıf düzeyinde Fen Bilimleri dersinin verilmesine ilgili görüşleri nelerdir?” görüşme sorusuna ilişkin olarak öğretmenlerle yapılan görüşmelerden elde edilen görüşler ve bu görüşlere ilişkin frekans dağılımları Tablo 3'de verilmiştir.

Tablo 3.

Öğretmenlerin ilkokul 3. Sınıfta Fen Bilimleri Dersinin Verilmesine Ilişkin Görüşlerinin Frekans Dağılımı.

\begin{tabular}{|c|c|c|c|c|c|c|}
\hline \multirow[t]{2}{*}{ Tema } & \multirow[t]{2}{*}{ Alt Tema } & \multirow[t]{2}{*}{ Kodlar } & \multirow{2}{*}{$\begin{array}{c}\text { Üst Grup } \\
\mathbf{f}\end{array}$} & \multirow{2}{*}{$\begin{array}{c}\text { Orta } \\
\text { Grup }\end{array}$} & \multirow{2}{*}{$\frac{\text { Alt Grup }}{\mathbf{f}}$} & \multirow{2}{*}{$\frac{\text { Toplam }}{\mathbf{f}}$} \\
\hline & & & & & & \\
\hline & Fen & Öğrencilerin fen & & & & \\
\hline ПIKOKUL 3. & konularının & bilimlerine olan ilgilerini & 7 & 8 & 9 & 24 \\
\hline Bilimleri & Fen Bilimleri & artırdığını düşünüyorum & & & & \\
\hline Dersinin & dersinde & Öğrencileri 4. sınıf Fen & & & & \\
\hline Verilmesine & verilmesini & Bilimleri dersine & 8 & 4 & 6 & 18 \\
\hline illişkin Görüşler & $\begin{array}{l}\text { olumlu } \\
\text { buluyorum }\end{array}$ & $\begin{array}{l}\text { hazırlayıcı nitelikte } \\
\text { olduğunu düşünüyorum }\end{array}$ & & & & \\
\hline
\end{tabular}

Tablo 3 incelendiğinde; her üç okul grubunda da öğretmenlerin tamamının fen konularının ilkokul 3. sınıfta Fen Bilimleri dersinde verilmesini olumlu buldukları görülmektedir. Üst grupta görev yapan 7 öğretmenin; orta grupta 8 öğretmenin ve alt grupta ise 9 öğretmenin ilkokul 3. sınıfta Fen bilimleri dersinin verilmesinin öğrencilerin fen bilimlerine olan ilgilerini artırdığını düşündükleri belirlenmiştir. Ayrıca üst grupta görev yapan 8 öğretmenin; orta grupta 4 öğretmenin ve alt grupta ise 6 öğretmenin ilkokul 3. sınıf Fen bilimleri dersini, öğrencileri 4. sınıf Fen bilimleri dersine hazırlayıcı nitelikte bulduğu tespit edilmiştir. Öğretmenlerin bu soruya ilişkin görüşlerinden bazıları aşağıda verilmiştir:

Üö-7: "...Şimdi şöyle; 3. sınıftan 4. sınıfa bir hazırlık olması bakımından çok güzel...”

Oö-12: "...Aslında iyi olmuş ayırmaları. Olumlu. Hayat bilgisinin içinde o kadar çok konu var ki; bir de fen bilimleri girdim mi sanki arada kaynayıp gidiyormuş gibi oluyordu. Ya da hayat bilgisi dersi boğuluyordu. Fen bilimlerinin ayrılması iyi olmuş. Çocukların daha çok ilgisini çekiyor. Bir de ne biliyim daha mı büyüdük diye hissettiler kendilerini ayrı bir ders almaları ilgilerini çekti yani güzel oldu..."

Aö-8: "...Yani şu anki konular geçen yıllarda yoktu hayat bilgisinde. Öyle elektrik konusu, dünyanın yapısı falan yoktu. Yani bence iyi olmuş. Olumlu. Çünkü en azından 4. sınıfta ilk defa karşılaşıyorlar ve daha zor oluyor. En azından bir basamak olmuş oldu, basit düzeyde anlayacakları kadar. Iyi olmuş. Olumlu, bence..."

\section{Programda Yer Alan Kazanımlar}

"Öğretmenlerin, İlkokul 3. Sınıf Fen Bilimleri Dersi Öğretim Programında yer alan kazanımlara ilişkin görüşleri nelerdir?" görüşme sorusuna ilişkin olarak öğretmenlerle yapılan görüşmelerden elde edilen görüşler ve bu görüşlere ilişkin frekans dağılımları Tablo 4'de verilmiştir.

Tablo 4.

Öğretmenlerin Programda Yer Alan Kazanımlara ilişkin Görüşlerinin Frekans Dağılımı.

\begin{tabular}{llcccc}
\hline \multirow{2}{*}{ Tema } & Kodlar & Üst Grup & Orta Grup & Alt Grup & Toplam \\
\cline { 2 - 6 } & $\begin{array}{l}\text { Kazanımlar, öğrencilerin seviyesine } \\
\text { uygun }\end{array}$ & 11 & $\mathbf{f}$ & $\mathbf{f}$ & $\mathbf{f}$ \\
\hline $\begin{array}{l}\text { Kazanımlara } \\
\text { Klişkin Görüşler }\end{array}$ & $\begin{array}{l}\text { Kazanımlar, anlamlı öğrenme için } \\
\text { uygun } \\
\text { Kazanımlara okulun mevcut } \\
\text { kaynaklarıyla ulaşılabilir }\end{array}$ & 11 & 10 & 11 & 33 \\
& 11 & 5 & 2 & 31 \\
\hline
\end{tabular}

Tablo 4 incelendiğinde; her üç okul grubunda da 11'er öğretmenin kazanımları, öğrencilerin seviyesine uygun buldukları görülmektedir. Üst grupta görev yapan 11 öğretmenin; orta ve alt grupta ise 10'ar öğretmenin kazanımları, anlamlı öğrenme için uygun buldukları yani kazanımların öğrenciyi ezbere yönlendirici nitelikte 
olmadığını düşündükleri tespit edilmiştir. Öğretmenlerin bu soruya ilişkin görüşlerinden bazıları aşağıda verilmiştir:

ÜÖ-10: "...Yani kazanımlar ulaşılabilir. Biz okul olarak da biraz şanslıyız laboratuvar anlamında ama başka okullar için bilemiyorum..."

Oö-9: "...Kazanımlar seviyeye kesinlikle uygun. Kesinlikle uygun yani biz herhangi bir sıkıntı yaşamadık..."

AÖ-1:"...Ben anlamlı öğrenmeye uygun buluyorum; ezbere yönelik değil..."

\section{Programda Yer Alan Konular}

"Öğretmenlerin, Illkokul 3. Sınıf Fen Bilimleri Dersi Öğretim Programında yer alan konulara ilişkin görüşleri nelerdir?" görüşme sorusuna ilişkin olarak öğretmenlerle yapılan görüşmelerden elde edilen görüşler ve bu görüşlere ilişkin frekans dağılımları Tablo 5'de verilmiştir.

Tablo 5.

Öğretmenlerin Programda Yer Alan Konulara iliş̧kin Görüşlerinin Frekans Dağılımı.

\begin{tabular}{llcccc}
\hline \multirow{2}{*}{ Tema } & \multirow{2}{*}{ Kodlar } & Üst Grup & Orta Grup & Alt Grup & \multicolumn{2}{c}{ Toplam } \\
\cline { 2 - 5 } & Konular, öğrencilerin seviyesine & $\mathbf{f}$ & $\mathbf{f}$ & $\mathbf{f}$ & $\mathbf{f}$ \\
\hline \multirow{2}{*}{ Konulara ilişkin } & 11 & 10 & 10 & 31 \\
Görüşler & uygun & 11 & 10 & 10 & 31 \\
& Konular, kazanımlara uygun & 12 & 12 & 10 & 34 \\
\hline
\end{tabular}

Tablo 5 incelendiğinde; üst ve orta grupta görev yapan öğretmenlerin tamamının; alt grupta ise 10 öğretmenin konuları günlük yaşamla ilişkili buldukları belirlenmiştir. Öğretmenlerin bu soruya ilişkin görüşlerinden bazıları aşağıda verilmiştir:

ÜÖ-7:“...Kazanımları çok güzel denkleştirmiş, yani konular kazanımlarla alakalı, ilişkilendirilmiş...”

OÖ-9: “...Günlük yaşamla ilişkili. Yani bu yaş grubunun günlük hayatında kullanması gereken bilgiler var. Yani çocuğa, konuyu anlattığınız zaman kendi günlük hayatından örnekler verebiliyor..."

AÖ-11:“...Yani benim öğrencilerimin seviyesine uygun. 3. sınıf için uygun. Hiç zorlanmadık...”

\section{Programda Etkinlik Örneklerine Yer Verilmemesi}

"Öğretmenlerin, Ilkokul 3. Sınıf Fen Bilimleri Dersi Öğretim Programında öğretme-öğrenme ve değerlendirme süreçlerine yönelik etkinlik örneklerinin yer almamasına ilişkin görüşleri nelerdir?" görüşme sorusuna ilişkin olarak öğretmenlerle yapılan görüşmelerden elde edilen görüşler ve bu görüşlere ilişkin frekans dağııımları Tablo 6'da verilmiştir.

Tablo 6.

Öğretmenlerin Programda Etkinlik Örneklerinin Yer Almamasına ilişkin Görüşlerinin Frekans Dağı̆ımı.

\begin{tabular}{|c|c|c|c|c|c|}
\hline \multirow{2}{*}{ Tema } & \multirow{2}{*}{ Kodlar } & Üst Grup & Orta Grup & Alt Grup & Toplam \\
\hline & & $f$ & $f$ & $f$ & $f$ \\
\hline $\begin{array}{l}\text { Programda } \\
\text { Etkinlik } \\
\text { Örneklerinin }\end{array}$ & $\begin{array}{l}\text { Yol gösterici olması açısından etkinlik } \\
\text { örnekleri olmalı }\end{array}$ & 12 & 11 & 11 & 34 \\
\hline $\begin{array}{l}\text { Yer } \\
\text { Almamasına } \\
\text { Illişkin Görüşler }\end{array}$ & $\begin{array}{l}\text { Etkinlik örneklerinin olmamasını bir } \\
\text { eksiklik olarak görmüyorum }\end{array}$ & - & 1 & 1 & 2 \\
\hline
\end{tabular}

Tablo 6 incelendiğinde; orta ve alt grupta görev yapan 11'er öğretmenin; üst grupta ise öğretmenlerin tamamının yol gösterici olması açısından programda etkinlik örneklerinin olması gerektiğini belirttikleri görülmektedir. Öğretmenlerin bu soruya ilişskin görüşlerinden bazıları aşă̆ıda verilmiştir:

ÜÖ-10:"...Yani evet olsa daha iyi olabilirdi. Daha yol gösterici olabilirdi tabi..."

oö-11: “...Yani şunu gördük ki; hani olmasa da olur. Çünkü hani öğretmen kendisi yapıyor zaten..."

AÖ-7:"...Olsa iyi olur yani. Hani bizim için kolay oluyor. En azından elimizde bir örnek oluyor..."

\section{Öğretme-öğrenme Sürecinde Yapılan Etkinliklerin Yeterliği}

"Öğretmenlerin, programın hedeflerine ulaşmayı sağlamak üzere sınıfta gerçekleştirdikleri öğretmeöğrenme sürecinin yeterliğine ilişkin görüşleri nelerdir?” görüşme sorusuna ilişkin olarak öğretmenlerle yapılan görüşmelerden elde edilen görüşler ve bu görüşlere ilişkin frekans dağılımları Tablo 7'de verilmiştir. 
Tablo 7.

Öğretmenlerin Öğretme-Öğrenme Sürecinde Yapmış Oldukları Etkinliklerin Yeterliğine ilişkin Görüşlerinin Frekans Dağııımı.

\begin{tabular}{|c|c|c|c|c|c|}
\hline \multirow{2}{*}{ Tema } & \multirow{2}{*}{ Kodlar } & Üst Grup & Orta Grup & Alt Grup & Toplam \\
\hline & & $f$ & $f$ & $f$ & $f$ \\
\hline \multirow{7}{*}{$\begin{array}{l}\text { Öğretme- } \\
\text { Öğrenme } \\
\text { Sürecinde } \\
\text { Yapılmış Olan } \\
\text { Etkinliklerin } \\
\text { Yeterliğine } \\
\text { illişkin Görüşler }\end{array}$} & $\begin{array}{l}\text { Konuları günlük yaşamla } \\
\text { ilişkilendirerek yeterli olmasını } \\
\text { sağlıyorum }\end{array}$ & 4 & 2 & 5 & 11 \\
\hline & $\begin{array}{l}\text { Derste, görsel materyaller kullanarak } \\
\text { yeterli olmasını sağlıyorum }\end{array}$ & 2 & 4 & 3 & 9 \\
\hline & $\begin{array}{l}\text { Konularla ilgili sık tekrar yaparak } \\
\text { yeterli olmasını sağlıyorum }\end{array}$ & 2 & 3 & 1 & 6 \\
\hline & $\begin{array}{l}\text { Konularla ilgili deneyler yaparak } \\
\text { yeterli olmasını sağlıyorum }\end{array}$ & 1 & 2 & - & 3 \\
\hline & $\begin{array}{l}\text { Derste, grup çalışmaları yaptırarak } \\
\text { yeterli olmasını sağlıyorum }\end{array}$ & 2 & - & - & 2 \\
\hline & $\begin{array}{l}\text { Laboratuvar yeterli donanıma sahip } \\
\text { olmadığı için yetersiz olduğunu } \\
\text { düşünüyorum }\end{array}$ & 1 & - & 3 & 4 \\
\hline & $\begin{array}{l}\text { Sinıf mevcudu kalabalık olduğu için } \\
\text { yetersiz olduğunu düşünüyorum }\end{array}$ & - & 1 & - & 1 \\
\hline
\end{tabular}

Tablo 7 incelendiğinde; üst grupta görev yapan 4 öğretmenin konuları günlük yaşamla ilişkilendirdikleri için; orta grupta görev yapan 4 öğretmenin derste görsel materyaller kullandıkları için; alt grupta görev yapan 5 öğretmenin ise konuları günlük yaşamla ilişkilendirdikleri için öğretme-öğrenme sürecinde yapmış oldukları etkinlikleri yeterli buldukları tespit edilmiştir. Ayrıca üst grupta görev yapan 1 öğretmenin ve alt grupta 3 öğretmenin laboratuvarın yeterli donanıma sahip olmaması nedeniyle öğretme-öğrenme sürecinde yapmış oldukları etkinlikleri yetersiz buldukları belirlenmiştir. Öğretmenlerin bu soruya ilişkin görüşlerinden bazıları aşağıda verilmiştir:

ÜÖ-9:"...Daha çok ben grup çalışması verdim çocuklara. Işte grup içinde çalıştılar. O çalışmaya istekli olmayan çocuklar da o zaman aralarına katıldı..."

OÖ-4: "...Sılk tekrar, süresi şey olduğu için fazla olduğu için tekrara fazla yer verdiğin için, genelde en kötü öğrenci bile daha iyi..."

AÖ-4:“...Çocuklara anlatırken görsel olarak anlattığım için çocuklarda daha kalıcı oldu. Daha da hoşlarına gitti..."

\section{Tercih Edilen Ölçme Araçları}

"Öğretmenlerin, programın hedeflerine ulaşııp ulaşılmadığını belirlemek için tercih ettikleri ölçme araçlarına ilişkin görüşleri nelerdir?" görüşme sorusuna ilişkin olarak öğretmenlerle yapılan görüşmelerden elde edilen görüşler ve bu görüşlere ilişkin frekans dağılımları Tablo 8'de verilmiştir.

Tablo 8.

Öğretmenlerin Tercih Ettikleri Ölçme Araçlarına iliş̧kin Görüşlerinin Frekans Dağı̆ımı.

\begin{tabular}{|c|c|c|c|c|c|}
\hline \multirow[t]{2}{*}{ Tema } & \multirow[t]{2}{*}{ Kodlar } & $\begin{array}{l}\text { Üst } \\
\text { Grup }\end{array}$ & $\begin{array}{l}\text { Orta } \\
\text { Grup }\end{array}$ & $\begin{array}{c}\text { Alt } \\
\text { Grup }\end{array}$ & Toplam \\
\hline & & $f$ & $f$ & $f$ & $f$ \\
\hline \multirow{7}{*}{$\begin{array}{l}\text { Tercih Edilen Ölçme Araçlarına İlişkin } \\
\text { Görüşler }\end{array}$} & Çoktan seçmeli test & 8 & 9 & 9 & 26 \\
\hline & Doğru-yanlış testi & 2 & 2 & 3 & 7 \\
\hline & Çalışma kağıtları & 1 & 2 & 2 & 5 \\
\hline & Derse katılım & 2 & 2 & 1 & 5 \\
\hline & Sözlü sunum & 2 & 1 & 1 & 4 \\
\hline & $\begin{array}{l}\text { Öz ve akran } \\
\text { değerlendirme }\end{array}$ & 2 & 1 & 1 & 4 \\
\hline & Öğrenci ürün dosyası & 2 & 1 & 1 & 4 \\
\hline
\end{tabular}

Tablo 8 incelendiğinde; ölçme aracı olarak üst grupta görev yapan 8 öğretmenin; orta grupta ve alt grupta görev yapan 9'ar öğretmenin çoktan seçmeli testi tercih ettikleri tespit edilmiştir. Öğretmenlerin bu soruya ilişkin görüşlerinden bazıları aşağıda verilmiştir: 
Üö-4:"...Her öğrencinin derste yaptığı bütün çalışmaları koyduğu bir dosyası var ve bence bu dosya öğrencinin derste neler öğrendiği hakkında yeterli bilgiyi veriyor..."

OÖ-8: "...Öğrencilere her konu bitiminde o konuyla ilgili çalışma kâğıtları dağıtıyorum ve o çalışma kâğıtlarına göre öğrencilerin konuyu ne kadar öğrendikleri hakkında bir fikir sahibi oluyorum..."

AÖ-12:"...Genellikle on sorudan oluşan çoktan seçmeli testler hazırlayıp, öğrencilere uyguluyorum..."

\section{Ders Süresi}

“Öğretmenlerin, illkokul 3. sınıf Fen Bilimleri dersi için verilen süreye ilişkin görüşleri nelerdir?” görüşme sorusuna ilişkin olarak öğretmenlerle yapılan görüşmelerden elde edilen görüşler ve bu görüşlere ilişkin frekans dağılımları Tablo 9'da verilmiştir.

Tablo 9.

Öğretmenlerin Ders Süresine Illişkin Görüşlerinin Frekans Dağılımı.

\begin{tabular}{llcccc}
\hline \multirow{2}{*}{ Tema } & \multirow{2}{*}{ Kodlar } & Üst Grup & Orta Grup & Alt Grup & Toplam \\
\cline { 3 - 6 } & & $\mathbf{f}$ & $\mathbf{f}$ & $\mathbf{f}$ & $\mathbf{f}$ \\
\hline Ders Süresine & Ders için verilen süre yeterli & 11 & 7 & 9 & 27 \\
illişkin Belirtilen & Ders için verilen süre azaltılmalı & - & 2 & 1 & 3 \\
Görüşler & Ders için verilen süre artırılmalı & 1 & 3 & 2 & 6 \\
\hline
\end{tabular}

Tablo 9 incelendiğinde; üst grupta görev yapan 11 öğretmenin; orta grupta 7 öğretmenin ve alt grupta ise 9 öğretmenin ilkokul 3. sınıf Fen Bilimleri dersi için verilen süreyi yeterli buldukları görülmektedir. Öğretmenlerin bu soruya ilişkin görüşlerinden bazıları aşağıda verilmiştir:

Üö-7:"...Yeterli, yani konularına göre yeterli. Yani 3 saat gerçekten konularına göre çok güzel..."

oö-7: "...Süre yeterli. Yani bu konular, bu kazanımlarla bu süre örtüşüyor..."

Aö-4:"...Şu anda diyorum ya ben üniteleri erken bitirdim. Süre olarak şu anda azaltılmalı. Onun yerine mesela matematiğe verilse çok daha iyi olur..."

\section{Program Uygulanırken Karşılaşılan Zorlukları}

“Öğretmenlerin, İlk kez 2014-2015 öğretim yılında uygulamaya başlanılan İlkokul 3. Sınıf Fen Bilimleri Dersi Öğretim Programını uygularken yaşadıkları zorluklara ilişkin görüşleri nelerdir? görüşme sorusuna ilişkin olarak öğretmenlerle yapılan görüşmelerden elde edilen görüşler ve bu görüşlere ilişkin frekans dağılımları Tablo $10^{\prime}$ da verilmiştir.

Tablo 10.

Öğretmenlerin Programı Uygularken Zorluk Yaşayıp Yaşamadıklarına ilişskin Görüşlerinin Frekans Dağılımı.

\begin{tabular}{|c|c|c|c|c|c|}
\hline \multirow{2}{*}{ Tema } & \multirow{2}{*}{ Kodlar } & Üst Grup & Orta Grup & Alt Grup & Toplam \\
\hline & & $f$ & $f$ & $f$ & $f$ \\
\hline Program & Zorluk yaşamadım & 9 & 6 & 8 & 23 \\
\hline $\begin{array}{l}\text { Uygulanırken } \\
\text { Zorluk Yaşanılıp } \\
\text { Yaşanılmadığına } \\
\text { İlişkin Görüşler }\end{array}$ & $\begin{array}{l}\text { Öğretmen kılavuz kitabının } \\
\text { olmamasından dolayı zorluk } \\
\text { yaşadım }\end{array}$ & 3 & 6 & 4 & 13 \\
\hline
\end{tabular}

Tablo 10 incelendiğinde; üst grupta görev yapan 9 öğretmenin; orta grupta 6 öğretmenin ve alt grupta ise 8 öğretmenin programı uygularken bir zorluk yaşamadıkları görülmektedir. Öğretmenlerin bu soruya ilişkin görüşlerinden bazıları aşağıda verilmiştir:

ÜÖ-7: “...Elimizde ilgili şey yoktu, kılavuz kitabımız. Kılavuz kitap olmadığı için de zorlandık..."

OÖ-3:"...Kılavuz kitabımız olsaydı daha kolay olurdu..."

AÖ-11:"...Hiç zorlanmadım. Çok ekstra böyle bir fazlalık, bir yük getirmedi, zorlanmadık..."

\section{Programın Güçlü Yönleri}

“Öğretmenlerin, İlkokul 3. Sınıf Fen Bilimleri Dersi Öğretim Programının güçlü olan yönlerine ilişkin görüşleri nelerdir? görüşme sorusuna ilişkin olarak öğretmenlerle yapılan görüşmelerden elde edilen görüşler ve bu görüşlere ilişkin frekans dağılımları Tablo 11 'de verilmiştir. 
Tablo 11.

Öğretmenlerin Programın Güçlü Yönlerine Ilişkin Görüşlerinin Frekans Dağılımı.

\begin{tabular}{|c|c|c|c|c|c|}
\hline \multirow{2}{*}{ Tema } & \multirow{2}{*}{ Kodlar } & Üst Grup & Orta Grup & Alt Grup & Toplam \\
\hline & & $\mathbf{f}$ & $\mathbf{f}$ & $\mathbf{f}$ & $\mathbf{f}$ \\
\hline \multirow{4}{*}{$\begin{array}{l}\text { Programın } \\
\text { Güçlü Yönlerine } \\
\text { İlişkin Görüşler }\end{array}$} & Günlük yaşamla ilişkili olması & 7 & 8 & 6 & 21 \\
\hline & $\begin{array}{l}\text { Öğrencilerin fen bilimlerine ilgi } \\
\text { duymasını sağlaması }\end{array}$ & 4 & 4 & 4 & 12 \\
\hline & $\begin{array}{l}\text { Öğrencilerin seviyesine uygun } \\
\text { olması }\end{array}$ & 2 & 5 & 3 & 10 \\
\hline & $\begin{array}{l}\text { Öğrencileri 4. sınıf Fen Bilimleri } \\
\text { dersine hazırlayıcı nitelikte olması }\end{array}$ & 4 & - & 2 & 6 \\
\hline
\end{tabular}

Tablo 11 incelendiğinde; üst grupta görev yapan 7 öğretmenin; orta grupta görev yapan 8 öğretmenin ve alt grupta görev yapan 6 öğretmenin ise programın günlük yaşamla ilişkili olmasını programın güçlü yönlerinden birisi olarak gördükleri belirlenmiştir. Öğretmenlerin bu soruya ilişkin görüşlerinden bazıları aşağıda verilmiştir:

Üö-9:"...Yani şöyle fen bilimleri daha böyle evindeki mutfakla ilgili. İşte çevresinde gördükleriyle ilgili olduğu için benim hoşuma gitti program. Yani çocuğun yaşantısıyla ilgili. Örneğin; işte suyun halleri. Çocuk bunu yaşıyor, mutfakta görüyor, işte elektrikli araçlar evinde görüyor çocuk. Yani daha çok yani çocuğun yaşantısıyla ilgili olduğu için güzel..."

oö-3:"...Çocukların seviyesine uygundu, bence en güçlü yanı buydu..."

AÖ-8:"...Ben fen gelecek denildiğinde hani biraz düşündüm açıkçası nasıl olacak hani 3. sınıf düzeyine diye ama basitleştirmişler hani çok yoğunlaştırmamışlar konuları. O açıdan iyi. 4. sınıfa hazırlık oluyor...

\section{Programın Zayıf Yönleri}

“Öğretmenlerin, İlkokul 3. Sınıf Fen Bilimleri Dersi Öğretim Programının zayıf olan yönlerine ilişkin görüşleri nelerdir? görüşme sorusuna ilişkin olarak öğretmenlerle yapılan görüşmelerden elde edilen görüşler ve bu görüşlere ilişkin frekans dağılımları Tablo 12'de verilmiştir.

Tablo 12.

Öğretmenlerin Programın Zayıf Yönlerine ilişkin Görüşlerinin Frekans Dağılımı.

\begin{tabular}{llcccc}
\hline \multirow{2}{*}{ Tema } & \multirow{2}{*}{ Kodlar } & Üst Grup & Orta Grup & Alt Grup & Toplam \\
\cline { 3 - 6 } & Programda etkinlik örneklerinin yer & $\mathbf{f}$ & $\mathbf{f}$ & $\mathbf{f}$ & $\mathbf{f}$ \\
\hline \multirow{3}{*}{$\begin{array}{l}\text { Plmaması } \\
\text { Yönlerine İlişkin }\end{array}$} & 7 & 6 & 6 & 19 \\
Görüşler & Ögürenci çalışma kitabının olmaması & 4 & 4 & 6 & 11 \\
& Öğretmen kılavuz kitabının & 1 & 3 & 3 & 10 \\
& Olmaması & 2 & 2 & 3 & 7 \\
\hline
\end{tabular}

Tablo 12 incelendiğinde; üst grupta görev yapan 7 öğretmenin; orta grupta alt grupta görev yapan 6'şar öğretmenin ise programda etkinlik örneklerinin yer almamasını programın zayıf yönlerinden biri olarak gördükleri belirlenmiştir. Öğretmenlerin bu soruya ilişkin görüşlerinden bazıları aşağıda verilmiştir:

ÜÖ-3:"...Öğrencilere yönelik bir çalışma kitabının olmaması yönünden zayıf..."

oö-2:"...Okul araç gereçlerinin tam teşekküllü olmaması..."

AÖ-10:"...Örnekler eksik, biz onu kendimiz tamamlamaya çalıştık. Etkinlikler olmalıydı, olsa çok daha güzel olurdu. Onlar eksik..."

\section{Programa ilişkin Öneriler}

"Öğretmenlerin, uygulamaları sonucunda ilkokul 3. Sınıf Fen Bilimleri Dersi Öğretim Programının geliştirilmesine yönelik önerileri nelerdir? görüşme sorusuna ilişkin olarak öğretmenlerle yapılan görüşmelerden elde edilen görüşler ve bu görüşlere ilişkin frekans dağılımları Tablo 13’de verilmiştir.

Tablo 13 incelendiğinde; üst grupta ve orta grupta görev yapan 8'er öğretmenin ve alt grupta görev yapan 7 öğretmenin ise programa etkinlik örneklerinin konulmasını önerdikleri belirlenmiştir. Öğretmenlerin bu soruya ilişkin görüşlerinden bazıları aşağıda verilmiştir:

Üö-12:"...Etkinlikler konulursa çok daha başarılı olur..."

oö-2:"...Çalışma kitabı ve öğretmen kılavuzunu seneye milli eğitim çıkartırsa; fen dersinde çok daha başarılı olunacağına inanıorum..." 
AÖ-11:"...Okuldaki kaynakların yani laboratuvardaki kaynakların çok yeterli olduğunu düşünmüyorum. ilkokulların materyallerinin bakanlık tarafından daha geliştirilmesi lazım ki; çocuklara daha eğlenceli ve daha verimli bir şekilde ders işleyelim diye düşünüyorum..."

Tablo 13.

Öğretmenlerin Programa iliş̧kin Önerilerinin Frekans Dağılımı.

\begin{tabular}{|c|c|c|c|c|c|}
\hline \multirow{2}{*}{ Tema } & \multirow{2}{*}{ Kodlar } & Üst Grup & Orta Grup & Alt Grup & Toplam \\
\hline & & $f$ & $\mathbf{f}$ & $f$ & $f$ \\
\hline \multirow{6}{*}{$\begin{array}{l}\text { Programa İlişkin } \\
\text { Öneriler }\end{array}$} & $\begin{array}{l}\text { Programa etkinlik örnekleri } \\
\text { konulmalı }\end{array}$ & 8 & 8 & 7 & 23 \\
\hline & $\begin{array}{l}\text { Öğrenci çalışma kitapları } \\
\text { hazırlanmalı }\end{array}$ & 5 & 4 & 4 & 13 \\
\hline & $\begin{array}{l}\text { Okullara laboratuvar malzemeleri } \\
\text { gönderilmeli }\end{array}$ & 1 & 5 & 6 & 12 \\
\hline & $\begin{array}{l}\text { Öğretmen kılavuz kitapları } \\
\text { hazırlanmalı }\end{array}$ & 3 & 3 & 3 & 9 \\
\hline & Konular detaylandırılmalı & 1 & 2 & 2 & 5 \\
\hline & $\begin{array}{l}\text { Ders kitabı görsel açıdan } \\
\text { zenginleştirilmeli }\end{array}$ & - & 1 & 2 & 3 \\
\hline
\end{tabular}

\section{Tartışma, Sonuç ve Öneriler}

Araştırma kapsamında elde edilen bulgular incelendiğinde, ilkokul 3. sınıf düzeyinde ilk kez uygulanacak olan Fen Bilimleri Dersi Öğretim Programına ilişkin program uygulanmaya başlamadan önce öğretmenlere herhangi bir bilgilendirmenin yapılmadığı belirlenmiştir. Demirtaş, Arslan, Yarar ve Tutkun (2015) tarafından 2013-2014 öğretim yılında ilk kez uygulamaya başlanan İlkokul 5. Sınıf Fen bilimleri Dersi Öğretim Programına yönelik yapılan çalışmada da benzer bir bulgu elde edilmiş ve yapılan çalışmada öğretmenler program hakkında bilgilendirilmediklerini belirtmiştir. Programa ilişkin herhangi bir bilgilendirme yapılmayan öğretmenlerin özellikle de o yıl ilk kez uygulanacak bir dersin programının uygulanması sürecinde sorunlarla karşılaşma intimalleri oldukça yüksektir. Fen programları ile ilgili yapılan birçok çalışmada bu görüşü destekler niteliktedir. Savran, Çakıroğlu ve Özkan (2002), Akpınar, Günay ve Hamurcu (2005), Öz (2007), Şeker, (2007), Yangın (2007), Kara (2008), Tekbıyık ve Akdeniz (2008) ve Unayağyol (2009) tarafından yapılan çalışmalarda, öğretmenler fen programlarının uygulanması sürecinde karşılaştıkları başlıca sorunlardan birisinin program hakkında yeterince bilgilendirilmemek olduğunu belirtmiştir.

Araştırma sonucunda elde edilen bir diğer önemli bulgu ise her üç okul grubunda da öğretmenlerin tamamının fen konularının 3. sınıf düzeyinde Fen Bilimleri adı altında ayrı bir ders olarak verilmesini olumlu bulmalarıdır. Alanyazında bu konuyla ilgili yapılan birçok çalışmada da benzer bulgular elde edilmiştir. Aybek ve Aslan (2015), Çalışoğlu, Tortum, Erişmiş ve Koçyiğit (2015), Çiftçi, Saban, Gündüz ve Olaç (2015), Ünişen ve Kaya (2015) ve Yıldırım ve Güngör Akgün (2015) tarafından yapılan çalışmalarda, öğretmenlerin Fen Bilimleri dersinin 3. sınıf düzeyinde verilmesini olumlu buldukları belirlenmiştir. İlk kez 2014-2015 öğretim yılında verilmeye başlanan Fen Bilimleri dersinin uygulandığı ilk yılda dersin uygulayıcıları olan öğretmenler tarafından olumlu olarak değerlendirilmesi ise dersin 3. sınıflarda verilmesinin ilkokul fen eğitimi açısından doğru bir adım olduğu şeklinde yorumlanabilir. Görüşleri alınan öğretmenler, 3. sınıfta verilen Fen Bilimleri dersinin öğrencilerin fen bilimlerine olan ilgilerini artırdığını belirtmiştir. Yani öğretmenler, 3. sınıf Fen Bilimleri dersinde öğrencilerin fen bilimlerine olan ilgilerinin Hayat Bilgisi dersine göre daha fazla olduğunu düşünmektedir. Topal (2009) tarafından yapılan çalışma da bu görüşü desteklemektedir. Topal (2009) tarafından yapılan çalışmada, sınıf öğretmenleri öğrencilerin fen derslerinde fen konularına olan ilgilerinin hayat bilgisi derslerinde fen konularına olan ilgilerinden daha fazla olduğunu belirtmiştir. Ayrıca yine öğretmenler, 3. sınıf Fen Bilimleri dersinin öğrencileri 4. sınıf Fen Bilimleri dersine hazırlayıcı nitelikte olduğunu belirtmiştir. Yani öğretmenler, 3. sınıf Fen Bilimleri dersinin Hayat Bilgisi dersine oranla öğrencileri 4. Sınıf Fen Bilimleri dersine daha iyi hazırladığını düşünmektedir. Demir (2006) ve Topal (2009) tarafından yapılan çalışmalar da bu görüşü desteklemektedir. Demir'in (2006) yapmış olduğu çalışmada, sınıf öğretmenlerinin, öğrencileri fen derslerine hazırlamada hayat bilgisi derslerini yetersiz buldukları belirlenmiştir. Topal'ın (2009) yapmış olduğu çalışmada ise sınıf öğretmenlerine göre hayat bilgisi dersi öğrencileri fen dersine kısmen hazırlamaktadır. 
Araştırma sonucunda, dikkat çeken bir diğer bulgu ise öğretmenlerin büyük çoğunluğunun yol gösterici olması açısından programda etkinlik örneklerinin olması gerektiğini düşünmeleridir. Öğretmenler, programda etkinlik örneklerine yer verilmesinin öğretme-öğrenme ve değerlendirme süreçlerini planlamada kendilerine yardımcı olacağını düşünmektedir. 2014-2015 öğretim yılında ilk kez uygulanan Fen Bilimleri dersinde, öğretmenlere programa yönelik bilgilendirmenin yapılmadı̆̆ı ve derse yönelik öğretmen kılavuz kitaplarının da verilmediği düşünüldüğünde; öğretmenlerin programda etkinlik örneklerinin yer almasını istemeleri oldukça doğal karşılanabilir. Öğretmenlerin, programda etkinlik örneği istemelerinin nedeni ise bir önceki programda yani 2005 Fen ve Teknoloji Dersi Öğretim Programında öğretmenlere yönelik bu tür etkinliklerin yer alması olabilir. Çünkü Doğan (2009) ve Kurtuluş ve Çavdar (2011) tarafından 2005 programına yönelik yapılan çalışmalar, öğretmenlerin programda yer alan etkinlik örneklerine ilişkin olumlu düşüncelere sahip olduğunu göstermektedir. Doğan (2009) tarafından yapılan çalışmada, öğretmenlerin programda yer alan etkinlikleri büyük oranda benimsedikleri ve uygulamaya çalıştıkları belirlenmiştir. Kurtuluş ve Çavdar (2011) tarafından yapılan çalışmada ise öğretmenlerin programda yer alan etkinliklerini ilgi çekici ve kalıcı öğrenmeyi sağlayıcı nitelikte buldukları belirlenmiştir.

Öğretmenler genel olarak programı olumlu bulmakla birlikte eksik yönlerinin olduğunu da belirtmişlerdir. Öğretmenler, etkinlik örneklerinin programda yer almamasını programın eksik yönlerinden biri olarak görmektedir. Öğretmenler, öğrencilerin derste öğrendiklerini pekiştirmelerini sağlayacak öğrenci çalışma kitabının olmamasını da yine programın eksik yönlerinden biri olarak görmektedir. Fen Bilimleri Dersi Öğretim Programına yönelik yapılan birçok çalışmada da benzer bulgulara ulaşıımışır. Çalışoğlu vd. (2015), Çiftçi vd. (2015) ve Yıldııım ve Güngör Akgün (2015) tarafından 3. Sınıf Fen Bilimleri Dersi Öğretim Programına; Demirtaş vd. (2015) tarafından da 5. Sınıf Fen Bilimleri Dersi Öğretim Programına yönelik yapılan çalışmalarda, öğretmenlerin öğrenci çalışma kitaplarının olmamasını önemli bir eksiklik olarak gördükleri belirlenmiştir. Ayrıca başarı düzeyi olarak özellikle orta ve alt grup okullarda görev yapan öğretmenler, programın bir diğer zayıf yönü olarak ise okullardaki araç-gereç eksikliğini belirtmişlerdir. Fen programlarına yönelik yapılan birçok çalışmada da benzer bulgulara ulaşılmıştır. Özdemir (2006), Şeker (2007), Kara (2008) ve Boyacı (2010), tarafından yapılan çalışmalarda, öğretmenlerin okullardaki araç gereç eksikliğini programın olumsuz bir özelliği olarak gördükleri belirlenmiştir. Alanyazında fen dersine yönelik yapılan çalışmalar incelendiğinde de öğretmenlerin fen programlarının uygulanmasında karşılaştıkları başlıca sorunlardan birisinin okullardaki araç gereç eksikliği olduğu görülmektedir. Akdeniz vd. (2002), Savran vd. (2002), Öz (2007), Erdem (2009), Unayağyol (2009), Demirtaş (2012), Aybek ve Aslan (2015), Çalışoğlu vd. (2015), Çiftçi vd. (2015) ve Yıldırım ve Güngör Akgün (2015) tarafından yapılan çalışmalarda bu görüşü destekleyen bulgular elde edilmiştir.

Araştırmada elde edilen sonuçlara dayanarak, Illkokul 3. Sınıf Fen Bilimleri Dersi Öğretim Programı ile ilgili herhangi bir bilgilendirme yapılmayan öğretmenlere yeni programla ilgili hizmet içi eğitim seminerleri, kursları vb. düzenlenmesi önerilebilir. Ayrıca öğretmenlerin önerilerinden de yola çıkılarak, öğretme-öğrenme ve değerlendirme süreçlerine yönelik etkinlik örneklerinin programa eklenmesi, programı uygularken, öğretmenlere rehberlik edecek bir öğretmen kılavuz kitabının hazırlanması ve de öğrencilerin 3. sınıf Fen Bilimleri dersinde öğrendikleri bilgileri pekiştirmelerini sağlayacak bir öğrenci çalışma kitabının hazırlanması önerilebilir. Özellikle orta ve alt grup okullarda görev yapan öğretmenlerin görüşleri doğrultusunda getirilebilecek bir diğer öneri ise okullardan fen derslerinde ihtiyaç duydukları araç-gereçlerle ilgili görüşlerin alınması ve bu araç-gereçlerin okullara gönderilerek okul laboratuvarlarının yeterli donanıma sahip hale getirilmesi olabilir.

\section{Bilgilendirme}

Bu çalışma birinci yazarın ikinci yazar danışmanlı̆ında hazırlanan doktora tezinden üretilmiştir. 


\section{References}

Akdeniz, A. R., Yiğit, N. ve Kurt, Ş. (2002). Yeni fen bilgisi öğretim programı ile ilgili öğretmenlerin düşünceleri. V. National Science and Mathematics Education Congress. METü Ankara, 16-18 Eylül 2002.

Akpınar, D., Günay, Y. ve Hamurcu, H. (2005). Fen bilgisi programlarının hedef ve içerik boyutuna ilişkin öğretmen görüşleri. Eğitim ve Bilim Dergisi, 30(136), 3-11.

Aybek, B. ve Aslan, S. (2015). Sınıf öğretmenlerinin ilkokul 3. Sınıf fen bilimleri dersi öğretim programına yönelik görüşlerinin değerlendirilmesi. Uluslararası Sosyal Araştırmalar Dergisi, 8(41), 883-894.

Aydın, Ö. (2007). Ilköğretim 4. ve 5. sınıf fen ve teknoloji dersi öğretim programına ilişkin öğretmen görüşleri (Kütahya il örneği). Unpublished master's thesis, Eskişehir Osmangazi Üniversitesi, Eskişehir.

Bayrak, A. (2009). Ilköğretim fen ve teknoloji dersi öğretim programına ilişkin öğretmen görüşleri (Erzincan ili örneği). Unpublished master's thesis, Gazi Üniversitesi, Eğitim Bilimleri Enstitüsü, Ankara.

Boyacı, K. (2010). 2005 ilköğretim 6. 7. ve 8. sınıf fen ve teknoloji öğretim programı, programın uygulanmasında yaşanan sorunlar ve çözüm önerilerine ilişkin öğretmen görüşleri. Unpublished master's thesis, Çukurova Üniversitesi, Adana.

Çalışoğlu, M., Tortum, T., Erişmiş, F. ve Koçyiğit, D. (2015). Yeni yapılandırılan 3. sınıf hayat bilgisi ve fen bilimleri derslerine yönelik öğretmen görüşleri. Uluslararası Multidisipliner Akademik Araştırmalar Dergisi, 2(2), 1-11

Çepni, S. ve Çil, E. (2013). Fen ve teknoloji programı ilköğretim 1. ve 2. kademe öğretmen el kitabı. Ankara: Pegem Akademi Yayıncılık.

Çiftçi, S., Saban, A., Gündüz, S. N. ve Olaç, F. T. (2015). Illkokul üçüncü sınıf öğretmenlerinin üçüncü sınıf fen bilimleri dersine ilişkin görüşleri. Uluslararası Eğitim Bilimleri Dergisi, 2(4), 333-347.

Demir, S.. (2006). Ilköğretim programında okutulmakta olan hayat bilgisi derslerinin, öğrencileri fen bilgisi derslerine hazırlamadaki etkileri. Unpublished master's thesis, Ondokuz Mayıs Üniversitesi, Samsun.

Demirtaş, Z. (2012). Ilköğretim fen ve teknoloji dersi öğretim programının uygulanma sürecinin değerlendirilmesi. Unpublished doctoral dissertation, Abant İzzet Baysal Üniversitesi, Bolu.

Demirtaş, Z., Arslan, S., Yarar, i. \& Tutkun, Ö. F. (2015). Teachers' opinions about renewed fifth grade science lesson curriculum. The Online Journal of Counseling and Education, 4(2), 28-39.

Doğan, Y. (2009). Fen ve teknoloji dersi etkinliklerinin benimsenme ve uygulanma düzeyinin öğretmen görüşlerine göre incelenmesi. Unpublished doctoral dissertation, Gazi Üniversitesi, Ankara.

Erdem, M. (2009). 5. sınıf fen ve teknoloji eğitim programının yeterlilikleri ve karşılaşılan sorunlara ilişkin ögrretmen görüşlerinin belirlenmesi. Unpublished master's thesis, Sakarya Üniversitesi, Sakarya.

Fidan, N. (1986). Okulda öğrenme ve öğretme. Ankara: Kadıoğlu Matbaası.

Gökçe, ì. (2006). Fen ve teknoloji dersi programı ile öğretmen kılavuzunun içsel olarak değerlendirilmesi ve uygulamada karşılaşılan sorunlar (Balıkesir örneği). Unpublished master's thesis, Balıkesir Üniversitesi, Sosyal Bilimler Enstitüsü, Balıkesir.

Kara, S. (2008). ilköğretim altıncı sınıf düzeyinde fen ve teknoloji dersi öğretimi yapan öğretmenlerin yeni 2005 yılı fen ve teknoloji programının uygulanmasıyla ilgili görüş ve değerlendirmeleri (Afyonkarahisar il örneği). Unpublished master's thesis, Afyon Kocatepe Üniversitesi, Afyonkarahisar.

Karasar, N. (2006). Bilimsel araştırma yöntemi. Ankara: Nobel Yayın Dağıtım.

Kılıç, H. D. (2010). ilköğretim 6., 7. ve 8. sınıf fen ve teknoloji dersi öğretim programına ilişkin öğretmen görüşlerinin incelenmesi. Unpublished master's thesis, Erzincan Üniversitesi, Fen Bilimleri Enstitüsü, Erzincan.

Krippendorff, K. (2004). Content analysis an introduction to its methodology. London: Sage Publications.

Kurtuluş, N. ve Çavdar, O. (2011). Fen ve teknoloji programındaki etkinliklere yönelik öğretmen ve öğrenci düşünceleri. Necatibey Eğitim Fakültesi Elektronik Fen ve Matematik Eğitimi Dergisi, 5(1), 1-23.

M.E.B. (2013). Ilköğretim kurumları (ilkokullar ve ortaokullar) fen bilimleri dersi (3, 4, 5, 6, 7 ve 8. sınıflar) öğretim programı. Ankara: Milli Eğitim Bakanlığı.

Miles, M. B. \& Huberman, A. M. (1994). An expanded sourcebook qualitative data analysis. London: Sage Publications. 
Öz, B. (2007). 2001 ilköğretim fen bilgisi dersi ve 2005 ilköğretim fen ve teknoloji dersi programlarına ilişkin öğretmen görüşleri. Unpublished master's thesis, Çukurova Üniversitesi, Adana.

Özdemir, H. (2006). Ilköğretim okulları 4. ve 5. sınıf fen bilgisi öğretim programlarında karşılaşılan sorunlar ve çözüm önerilerine ilişkin öğretmen görüşleri (Konya ili örneklemi). Unpublished master's thesis, Selçuk Üniversitesi, Konya.

Savran, A., Çakıroğlu, J. ve Özkan, Ö. (2002). Fen bilgisi öğretmenlerinin yeni fen bilgisi programına yönelik düşünceleri. V. Ulusal Fen Bilimleri ve Matematik Eğitimi Kongresi. ODTÜ Ankara, 16-18 Eylül 2002.

Şeker, S. (2007). Yeni ilköğretim altıncı sınıf fen ve teknoloji dersi öğretim programının öğretmen görüşleri ışığında değerlendirilmesi (Gümüşhane ili örneği). Unpublished master's thesis, Karadeniz Teknik Üniversitesi, Trabzon.

Tekbıyık, A. ve Akdeniz, A. R. (2008). Illköğretim fen ve teknoloji dersi öğretim programını kabullenmeye ve uygulamaya yönelik öğretmen görüşleri. Necatibey Eğitim Fakültesi Elektronik Fen ve Matematik Eğitimi Dergisi, 2(2), 23-37.

Topal, N. (2009). 2004 fen ve teknoloji programının öğretmenler açısından değerlendirilmesi; Samsun örneği. Unpublished master's thesis, Ondokuz Mayıs Üniversitesi, Samsun.

Unayağyol, S. (2009). Öğretmenlerin fen ve teknoloji programının uygulanması sürecinde karşılaştı̆ı sorunlar ve çözüm önerileri. Unpublished master's thesis, Dokuz Eylül Üniversitesi, İzmir.

Ünişen, A. ve Kaya, E. (2015). Fen bilimleri dersinin ilkokul üçüncü sınıf programına alınmasıyla ilgili öğretmen görüşlerinin değerlendirilmesi. Adıyaman Üniversitesi Sosyal Bilimler Enstitüsü Dergisi, 8(20), 546-571.

Yangın, S. (2007). 2004 öğretim programı çerçevesinde ilköğretimde fen ve teknoloji dersinin öğretimine ilişkin öğretmen ve öğrenci görüşleri. Unpublished doctoral dissertation, Gazi Üniversitesi, Ankara.

Yıldırım, A. ve Şimşek, H. (2011). Sosyal bilimlerde nitel araştırma yöntemleri. Ankara: Seçkin Yayınclık.

Yıldırım, N. ve Güngör Akgün, Ö. (2015). İlkokul 3. sınıf öğretmenlerinin yenilenen fen bilimleri dersine ilişkin görüşleri. Ahi Evran Üniversitesi Kırşehir Eğitim Fakültesi Dergisi, 16(2), 199-21. 
